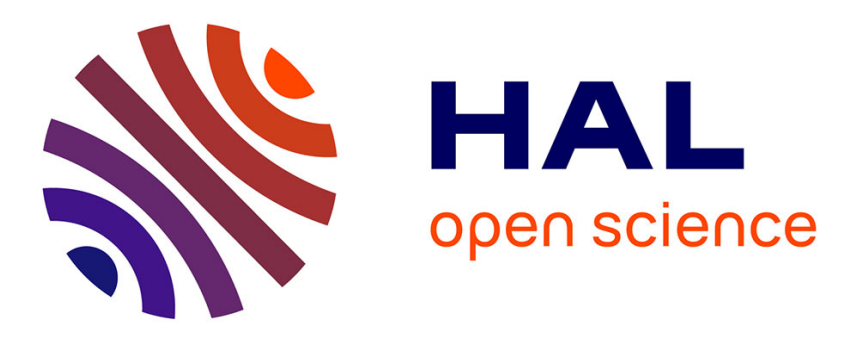

\title{
Variations in the light absorption coefficients of phytoplankton, nonalgal particles, and dissolved organic matter in coastal waters around Europe
}

M Babin, D Stramski, Gm Ferrari, Hervé Claustre, Annick Bricaud, G Obolensky, N Hoepffner

\section{To cite this version:}

M Babin, D Stramski, Gm Ferrari, Hervé Claustre, Annick Bricaud, et al.. Variations in the light absorption coefficients of phytoplankton, nonalgal particles, and dissolved organic matter in coastal waters around Europe. Journal of Geophysical Research. Oceans, 2003, 108 (C7), 10.1029/2001JC000882 . hal-03482957

\section{HAL Id: hal-03482957 \\ https://hal.science/hal-03482957}

Submitted on 21 Dec 2021

HAL is a multi-disciplinary open access archive for the deposit and dissemination of scientific research documents, whether they are published or not. The documents may come from teaching and research institutions in France or abroad, or from public or private research centers.
L'archive ouverte pluridisciplinaire HAL, est destinée au dépôt et à la diffusion de documents scientifiques de niveau recherche, publiés ou non, émanant des établissements d'enseignement et de recherche français ou étrangers, des laboratoires publics ou privés.

$$
\text { Copyright }
$$




\title{
Variations in the light absorption coefficients of phytoplankton, nonalgal particles, and dissolved organic matter in coastal waters around Europe
}

\author{
Marcel Babin, ${ }^{1,2}$ Dariusz Stramski, ${ }^{2}$ Giovanni M. Ferrari, ${ }^{3}$ Herve Claustre, \\ Annick Bricaud, ${ }^{1}$ Grigor Obolensky, ${ }^{4}$ and Nicolas Hoepffner ${ }^{3}$ \\ Received 19 March 2001; revised 12 March 2002; accepted 28 February 2003; published 2 July 2003.
}

[1] We measured the absorption properties of phytoplankton, nonalgal particles (NAP), and colored dissolved organic matter (CDOM) at about 350 stations in various coastal waters around Europe including the English Channel, Adriatic Sea, Baltic Sea, Mediterranean Sea, and North Sea. For comparison, we also collected data in the open ocean waters of North Atlantic. The exponential slope of the CDOM absorption spectrum varied within a narrow range around $0.0176 \mathrm{~nm}^{-1}\left(\mathrm{SD}=0.0020 \mathrm{~nm}^{-1}\right)$. When data from all the regions were considered altogether, the relationship between phytoplankton absorption and chlorophyll concentration was generally similar to the one previously established for open oceanic waters. Our coastal data, however, show that significant departures from the general trend may occur due to peculiar pigment composition and cell size. In some coastal areas, high phaeopigment concentrations gave rise to especially high blue-to-red ratio of phytoplankton absorption. The NAP absorption covaried with the particle dry weight. Most absorption spectra of these particles were well described by an exponential function with a slope averaging $0.0123 \mathrm{~nm}^{-1}\left(\mathrm{SD}=0.0013 \mathrm{~nm}^{-1}\right)$. In some highly turbid waters, the spectra exhibited a signature possibly associated with iron oxides. In the Baltic Sea, NAP absorption systematically showed lower values at wavelengths shorter than $440 \mathrm{~nm}$ than predicted from the fitted exponential function. Overall, the variability in the absorption properties of European coastal waters showed some consistent patterns despite the high diversity of the examined waters. Distinct features were identified in the phytoplankton and NAP components. An absorption budget is presented and parameterizations are proposed. INDEX TERMS: 4219 Oceanography: General: Continental shelf processes; 4552 Oceanography: Physical: Ocean optics; KEYWORDS: absorption, particles, CDOM, phytoplankton, optics

Citation: Babin, M., D. Stramski, G. M. Ferrari, H. Claustre, A. Bricaud, G. Obolensky, and N. Hoepffner, Variations in the light absorption coefficients of phytoplankton, nonalgal particles, and dissolved organic matter in coastal waters around Europe, J. Geophys. Res., 108(C7), 3211, doi:10.1029/2001JC000882, 2003.

\section{Introduction}

[2] The spectral absorption coefficient of seawater, $a(\lambda)$ $\left(\mathrm{m}^{-1}\right)$, is often subdivided into four additive components [e.g., Prieur and Sathyendranath, 1981; Roesler et al., 1989; Carder et al., 1991]:

$$
a(\lambda)=a_{w}(\lambda)+a_{\phi}(\lambda)+a_{\mathrm{NAP}}(\lambda)+a_{\mathrm{CDOM}}(\lambda) .
$$

\footnotetext{
${ }^{1}$ Laboratoire d'Océanographie de Villefranche, Centre National de la Recherche Scientifique, Université Pierre et Marie Curie, Villefranche-surMer Cedex, France.

${ }^{2}$ Marine Physcial Laboratory, Scripps Institution of Oceanography, University of California at San Diego, La Jolla, California, USA.

${ }^{3}$ Space Application Institute, C.E.C., Joint Research Centre, Ispra Varese, Italy.

${ }^{4}$ ACRI ST, Sophia Antipolis, France.
}

Copyright 2003 by the American Geophysical Union. 0148-0227/03/2001JC000882
These components account for the contributions of pure seawater $(w)$, phytoplankton $(\phi)$, nonalgal particles (NAP), and colored dissolved organic matter (CDOM). The variability of the absorption coefficient in oceanic (so-called "Case 1") waters has been thoroughly documented over the last decades. In such waters, all components except $a_{w}(\lambda)$ in equation (1) are often assumed to covary with chlorophyll $a$ concentration [Morel and Prieur, 1977; Prieur and Sathyendranath, 1981]. Different studies have shown that this assumption holds fairly well when considered at large to global scale. Morel [1988] derived an average relationship between the vertical attenuation coefficient for downward irradiance $\left(K_{d}\right)$ and chlorophyll $a$ concentration using a large data set representative of many different oceanic situations. The parameterization of $K_{d}$ he proposed can be used to estimate $a(\lambda)$ and ocean reflectance as a function of chlorophyll $a$ concentration. Similarly, Bricaud et al. [1995, 1998] and Cleveland [1995] published parameterizations of $a_{\phi}(\lambda)$ and $a_{p}(\lambda)$ (the latter is the total 
particulate absorption or the sum of $a_{\phi}(\lambda)$ and $\left.a_{\mathrm{NAP}}(\lambda)\right)$ as a function of chlorophyll $a$ concentration. Case 1 water parameterizations of absorption have been successfully used to build forward reflectance models [Gordon et al., 1988; Morel, 1988; Reynolds et al., 2001; Morel and Maritorena, $2001]$ and to develop ocean color algorithms. For instance, Gross et al. [2000] trained a neural network using a forward reflectance model based on the Morel [1988] parameterization of $a(\lambda)$, and validated it successfully against in situ data.

[3] When proposing parameterizations of the absorption coefficient for Case 1 waters, it was acknowledged that significant, seemingly random, variability occurs around general trends. It is the case, for instance, when the pigment composition and/or the pigment packaging effect differs from what is expected on average for a given chlorophyll $a$ concentration. It is also the case when the components in equation (1) do not covary, as shown in the Sargasso Sea by Siegel and Michaels [1996] who proposed that phytoplankton and so-called colored detrital matter (sum of $a_{\mathrm{NAP}}(\lambda)$ and $a_{\mathrm{CDOM}}(\lambda)$ ) should be considered as two independent components in Case 1 waters [see also the work of Carder et al., 1991]. Despite the variability around trends, absorption parameterizations allow us to constrain interpretation of inherent optical properties (IOPs) [e.g., Claustre et al., 2000], and inversion of reflectance and other apparent optical properties (AOPs) [e.g., Roesler and Perry, 1995], especially when spectral variations are considered (e.g., Siegel and Michaels [1996] for $K_{d}$ ).

[4] In coastal and inland (so-called Case 2) waters, variations in the shape and magnitude of the $a(\lambda)$ spectrum are poorly documented. The components in equation (1) are believed to vary independently [IOCCG, 2000]. Since the pioneering work of Kalle [1938] (see review by Kirk [1994]) the CDOM absorption has been frequently studied in Case 2 waters. As in Case 1 waters, the $a_{\mathrm{CDOM}}(\lambda)$ spectrum typically fits the exponential function [Bricaud et al., 1981]:

$$
a_{\mathrm{CDOM}}(\lambda)=\hat{a}_{\mathrm{CDOM}}\left(\lambda_{r}\right) \mathrm{e}^{\left(-S_{\mathrm{CDOM}}\left(\lambda-\lambda_{r}\right)\right)},
$$

where $\lambda_{r}(\mathrm{~nm})$ is a reference wavelength, $\hat{a}_{\mathrm{CDOM}}\left(\lambda_{r}\right)$ is the absorption estimate at reference wavelength, and $S_{\mathrm{CDOM}}$ $\left(\mathrm{nm}^{-1}\right)$ is the spectral slope of the $a_{\mathrm{CDOM}}(\lambda)$ spectrum. $S_{\mathrm{CDOM}}$ varies between 0.01 and $0.02 \mathrm{~nm}^{-1}$ according to Kirk [1994], and even over a wider range according to Kowalczuk [1999]. A true synthesis of the $S_{\mathrm{CDOM}}$ variability in coastal waters is difficult to achieve based on the existing data because studies were mostly conducted at limited regional scales, and furthermore, a significant part of the observed variability may have originated from experimental errors combined with the diversity of experimental protocols and spectral ranges considered.

[5] Not enough is known about absorption by particles in Case 2 waters to draw general conclusions about variability and trends. With regard to phytoplankton, the sources of variability in $a_{\phi}(\lambda)$, pigment composition [e.g., Hoepffner and Sathyendranath, 1991] and packaging [e.g., Bricaud et al., 1998], are well understood. Numerous laboratory and field studies of $a_{\phi}(\lambda)$ over the last two decades described the extent of variations in $a_{\phi}(\lambda)$ and the diversity of spectral signatures that can be encountered in aquatic environments, including Case 2 waters [e.g., Mitchell and Kiefer, 1988;
Bricaud and Stramski, 1990; Babin et al., 1993, 1996; Johnsen et al., 1994; Sosik and Mitchell, 1995; Cleveland, 1995; Allali et al., 1997; Stramski et al., 2001]. However, $a_{\phi}(\lambda)$ has not been documented in sufficient detail in various coastal waters to derive trends. There is no reason to assume a priori that specific parameterizations for Case 1 waters, such as the relationship between $a_{\phi}(\lambda)$ and chlorophyll $a$ concentration described by Bricaud et al. [1995], will be valid in coastal waters. Therefore one important question that remains is whether robust relationships between $a_{\phi}(\lambda)$ and chlorophyll $a$ concentration can be established in coastal waters where physical and chemical conditions as well as the structure of phytoplankton community are highly variable.

[6] Current understanding of variations in nonalgal particulate absorption, $a_{\mathrm{NAP}}(\lambda)$, is even more limited. We expect various signatures in the $a_{\mathrm{NAP}}(\lambda)$ spectra in Case 2 waters because of the presence of organic and inorganic absorbing particles of diverse nature [Bukata et al., 1995]. The actual range of variation in $a_{\mathrm{NAP}}(\lambda)$ and the potential diversity in spectral signatures are, however, poorly known. Data exist on total absorption, $a(\lambda)$, or $a(\lambda)-a_{w}(\lambda)[$ Whitlock et al., 1981; Witte et al., 1982; Kirk and Oliver, 1995] and total particulate absorption $a_{p}(\lambda)[$ Kirk, 1980, 1985; Kirk and Tyler, 1986; Oliver, 1990; Barnard et al., 1998] in turbid waters of different kinds (coastal, lakes, rivers, billabongs) but these studies do not provide direct information about nonalgal absorption because of confounding contributions by CDOM and/or phytoplankton. Other studies statistically derived $a_{\phi}(\lambda), a_{\mathrm{NAP}}(\lambda)$, and $a_{\mathrm{CDOM}}(\lambda)$ from apparent optical properties [Prieur and Sathyendranath, 1981; Bukata et al., 1981; Gallegos et al., 1990; Gallie and Murtha, 1992] and proposed typical spectral shapes for each of the components. Unfortunately, these approaches were limited in the discrimination between $a_{\mathrm{NAP}}(\lambda)$ and $a_{\mathrm{CDOM}}(\lambda)$ because of their similar spectral signature. Also, because $a_{\mathrm{NAP}}(\lambda)$ exhibits weak absorption compared with $a_{w}(\lambda)$ in the red part of the spectrum, it could lead to significant uncertainties in $a_{\mathrm{NAP}}(\lambda)$ estimates in this spectral region [see for instance Prieur and Sathyendranath, 1981].

[7] Few studies have been made in Case 2 waters, in which $a_{\mathrm{NAP}}(\lambda)$ was actually measured. Roesler et al. [1989] measured all three variable components of equation (1) in productive and CDOM-rich inland marine waters where NAP exhibited an exponential absorption signature with an average slope of $0.011 \mathrm{~nm}^{-1}$. Nelson and Guarda [1995] measured $a_{\phi}(\lambda), a_{\mathrm{NAP}}(\lambda)$, and $a_{\mathrm{CDOM}}(\lambda)$ along a cross-shelf section in the southern Atlantic Bight during spring and summer. They observed significant seasonal variations in spatial distribution of absorption properties related to freshwater discharge and phytoplankton species composition. It is not clear what the contribution of mineral particles was in their samples. Duarte et al. [1998] partitioned light absorption by marine particles into contributions by autotrophs, heterotrophic bacteria, heterotrophic flagellates, ciliates, and inorganic particles, using a multiple regression approach. They showed for one Case 2 Mediterranean bay that particle absorption in the blue part of the spectrum was dominated by mineral particles and that absorption by bacteria was as important as that by phytoplankton. While the study by Duarte et al. [1998] provides new insights into the complexity of light absorption by particles in one coastal 
Table 1. Locations and Dates of the Six COAST $\ell$ OOC Sampling Campaigns

\begin{tabular}{|c|c|c|c|c|}
\hline $\begin{array}{l}\text { COAST } \ell \text { OOC } \\
\text { Campaign }\end{array}$ & $\begin{array}{l}\text { Sampling } \\
\text { Platform }\end{array}$ & $\begin{array}{l}\text { Time } \\
\text { Period }\end{array}$ & Sampling Locations & $\begin{array}{c}\text { Number of } \\
\text { Stations Visited }\end{array}$ \\
\hline \multirow[t]{2}{*}{1} & RV Victor Hensen & 3-4 Apr. 1997 & $\begin{array}{l}\text { North Sea and English Channel: } \\
\text { Rhine and Thames River plume }\end{array}$ & 9 \\
\hline & & 4-22 Apr. 1997 & $\begin{array}{l}\text { Atlantic: open ocean from } \\
\text { Bay of Biscay to Canary Islands }\end{array}$ & 37 \\
\hline 2 & helicopter & 17-19 July 1997 & Lions Gulf: Rhone River plume & 15 \\
\hline 3 & helicopter & 21 July to 2 Aug. 1997 & $\begin{array}{l}\text { Northern Adriatic Sea: Po, Tagliamento, } \\
\text { and Adige River plumes, } \\
\text { and all along the coast between } \\
\text { the Po and Tagliamento Rivers }\end{array}$ & 40 \\
\hline 4 & RV Tethys II & 28 Sept. to 9 Oct. 1997 & $\begin{array}{l}\text { Lions Gulf: Rhone River plume } \\
\text { and around in Case } 1 \text { waters }\end{array}$ & 48 \\
\hline \multirow[t]{2}{*}{5} & RV Poseidon & 8-14 May 1998 & $\begin{array}{l}\text { English Channel: Loire, Seine, Thames, } \\
\text { Rhine, and Humber River plumes }\end{array}$ & 45 \\
\hline & & 15-16 May 1998 & $\begin{array}{l}\text { North Sea (German Bight): Ems, } \\
\text { Weser, and Elbe River plumes }\end{array}$ & 15 \\
\hline \multirow[t]{4}{*}{6} & helicopter & 1-5 Sept. 1998 & $\begin{array}{l}\text { English Channel: Tamar, Exe, Dart, } \\
\text { Avon, Yealm, Erme, Fowey, } \\
\text { and Fowey River plumes and all along } \\
\text { the coast between the Exe and Helford Rivers }\end{array}$ & 53 \\
\hline & & 11-13 Sept. 1998 & $\begin{array}{l}\text { North Sea: around the Dutch Texel Island } \\
\text { offshore, in the Marsdiep } \\
\text { and in the Wadden Sea }\end{array}$ & 31 \\
\hline & & 16-18 Sept. 1998 & $\begin{array}{l}\text { North Sea: between Borkum and } \\
\text { Wangerooge Friesland Islands in the } \\
\text { Wadden Sea and offshore, } \\
\text { and in the Weser River plume }\end{array}$ & 37 \\
\hline & & 22-25 Sept. 1998 & Baltic: West of Oder River plume & 57 \\
\hline Total & & & & 387 \\
\hline
\end{tabular}

system, it does not allow generalizations. Bowers et al. [1996] measured $a_{\mathrm{NAP}}(\lambda)$ of 100 water samples collected at one location in the Irish Sea. Particle absorption was measured after a heat treatment $\left(500^{\circ} \mathrm{C}\right.$ for 3 hours $)$ to remove all organic matter and retain only mineral particles. They observed spectra similar to those found for NAP in Case 1 surface waters [e.g., Bricaud et al., 1998], productive inland marine waters [Roesler et al., 1989], and deep waters [Yentsch, 1962] with an exponential shape and an average spectral slope $\left(S_{\mathrm{NAP}}\right)$ of ca. $0.011 \mathrm{~nm}^{-1}$. They also observed a relationship between $a_{\mathrm{NAP}}(440)$ and the mass concentration of suspended particulate matter (SPM, $\mathrm{g} \mathrm{m}^{-3}$ ). Similar $a_{\mathrm{NAP}}(\lambda)$ spectra were observed by Kratzer et al. [2000] who used the same procedure in the same area. It is worth noting that the study of Bowers et al. [1996] was probably the first one that addressed directly the determination of light absorption by marine mineral particles. The generalization and applicability of their results is, however, limited with regard to the following points: (1) the study was conducted at one location, (2) particles may have been altered by the heat treatment, and (3) the error associated with measurement of absorption was not assessed although this error may be especially high for mineral particles whose absorption-to-scattering ratio is expected to be very low [Bricaud and Morel, 1986].

[8] The above overview indicates several important problems that include: (1) it is not clear how accurate is the variability in $S_{\mathrm{CDOM}}$ for coastal waters reported in the literature, (2) we do not know if some general trends in $a_{\phi}(\lambda)$ variations exist in coastal waters, and if yes, whether they are similar or not to those observed in Case 1 waters, and (3) our knowledge about $a_{\mathrm{NAP}}(\lambda)$ in Case 2 waters is generally very poor. The first objective of the present study was therefore to thoroughly document variations in the components of the absorption coefficient in different coastal regions. To reach this goal, about 350 sites were visited in various waters along the European coast where the components of equation (1) were measured separately. The analysis of these data is focused on the variability of absorption components and absorption budget. The second objective was to improve our knowledge on the absorption properties of NAP in coastal waters in terms of the diversity of spectral signatures and the causes of this diversity. This study also contributes to bio-optics by extensively documenting absorption properties of coastal waters.

\section{Methods}

\subsection{Sampling}

[9] Sampling was conducted in various coastal waters around Europe during six campaigns in 1997 and 1998 as part of the Coastal Surveillance Through Observation of Ocean Color (COAST $\ell$ OOC) research project (Table 1). Our sampling objective was to encompass a large range of variation in absorption properties of coastal waters. More than 22 river plumes, other coastal environments (e.g., Wadden Sea), and many zones of resuspension were surveyed in the Adriatic Sea, Mediterranean Sea, Baltic Sea, North Sea, and English Channel (Figure 1). Additionally, samples were collected in the Atlantic Ocean between the Bay of Biscay and the Canary Islands (Figure 1) off the continental shelf (200-m isobath). These Case 1 water samples and a few of those collected in the Mediterranean Sea off the shelf are used for comparison with coastal waters.

[10] At each of 387 stations that were visited, a water sample for absorption measurements was collected at the surface either from a ship or from a helicopter. In most cases, an 8-1 Niskin bottle was used; otherwise, water was taken 


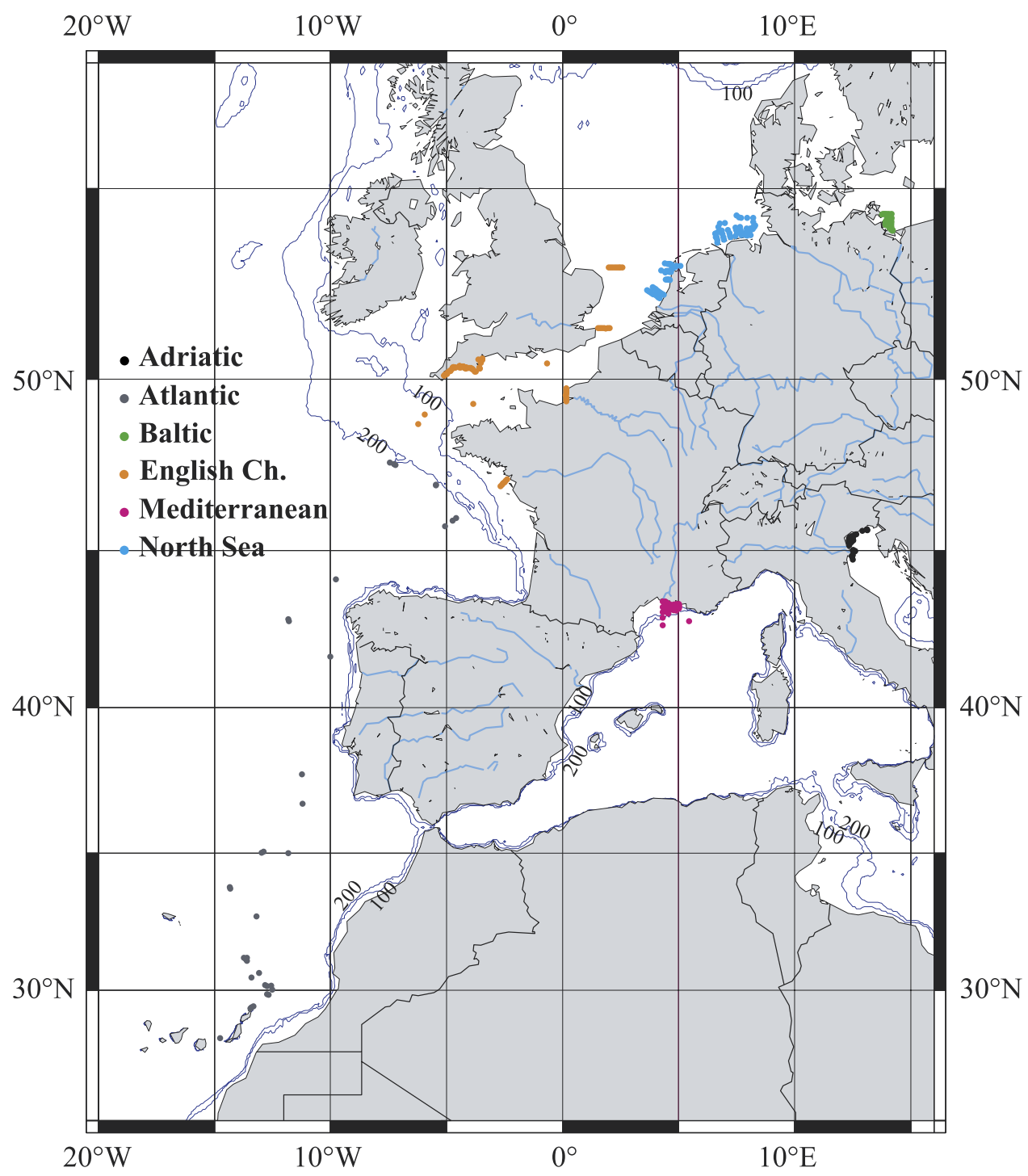

Figure 1. Location of 387 stations visited during the COAST $\ell$ OOC study. The partitioning into regions and the 100- and 200-m isobaths are shown. For practical reasons, the stations located in the plume of the Loire River are pooled with stations of the English Channel rather than with those of the Atlantic Ocean.

with a 6-1 polyethylene container (55 samples during campaigns 2 and 3). Onboard the ship, water samples were processed immediately after collection. When using the helicopter, water samples were kept in 6-1 polyethylene containers and processed on land no later than 2 hours after sampling. The use of the helicopter allowed us to locate fronts and other horizontal features, which facilitated sampling of waters exhibiting large differences in absorption properties. In most river plumes, it was possible to collect samples right in the mouth of the river. Some samples were collected in waters as shallow as $1 \mathrm{~m}$. Appropriate care was taken to avoid disturbing the water surface with the helicopter airflow.

[11] All protocols described below are compliant with those recommended for SeaWIFS calibration/validation activities [Mueller and Austin, 1995].

\subsection{CDOM Absorption}

[12] Seawater was filtered under low vacuum on a $0.22-\mu \mathrm{m}$ Millipore membrane, which was prerinsed with
$50 \mathrm{ml}$ of Milli-Q water. The absorbance of the filtered water was then measured in a $10-\mathrm{cm}$ quartz cuvette between 350 and $750 \mathrm{~nm}$ with $1-\mathrm{nm}$ increments using a dual beam spectrophotometer (Perkin Elmer, Lambda 12). Milli-Q water was used as a reference. A baseline correction was applied by subtracting the absorbance value averaged over a 5 -nm interval around $685 \mathrm{~nm}$ from all the spectral values. This spectral range around $685 \mathrm{~nm}$ was chosen because of negligible CDOM absorption, and very small temperature and salinity effects on water absorption [see Pegau et al., 1997, Figure 5]. After conversion into absorption coefficients, an exponential function (equation (2) with $\lambda_{r}=443$ $\mathrm{nm})$ was fitted by nonlinear regression to the data between 350 and $500 \mathrm{~nm}$. The $S_{\mathrm{CDOM}}$ estimates were obtained from this fitting approach. The spectral range we adopted here to estimate $S_{\mathrm{CDOM}}$ represents a good compromise because (1) it includes wavelengths where the signal is sufficiently high for a reliable estimation of $S_{\mathrm{CDOM}}$, (2) it excludes those wavelengths where the signal is low and therefore less 
significant for bulk AOPs and IOPs, and (3) it covers a spectral range that is useful for current and future biooptical applications. The baseline correction described above was found to be more robust than adding an intercept to the exponential function. The effect of any CDOM absorption at $685 \mathrm{~nm}$ had no impact on the retrieval of $S_{\text {CDOM. }}$. Out of 387 stations visited, 346 CDOM spectra and $S_{\mathrm{CDOM}}$ values are included in the final analysis. Measurements at some stations were missing and some spectra were discarded because they were either too noisy or contained obvious spectral artifacts.

\subsection{Particle Absorption}

[13] A seawater volume of $0.2-21$, depending on particle load, was filtered onto a 25-mm glass fiber filter (Whatman, $\mathrm{GF} / \mathrm{F}$ ) at low vacuum. Filters were then kept in liquid nitrogen for up to 2 months before analysis in the laboratory. The absorption spectrum of particles retained on the filter, $a_{p}(\lambda)$, was determined using the transmittance-reflectance $(T-R)$ technique [Tassan and Ferrari, 1995a, 1995b]. Absorbance and reflectance were measured between 380 and $750 \mathrm{~nm}$ with 1-nm increments using a dual beam spectrophotometer equipped with a $60-\mathrm{mm}$ integrating sphere (Perkin Elmer, Lambda 19). Correction for path length amplification was made using the expression given by Tassan and Ferrari [1995a]. This correction was shown to be less site and species dependent when using the $T-R$ technique [Tassan and Ferrari, 1998] and it was validated on the Adriatic Sea samples of the COAST $\ell$ OOC project by comparison with measurements performed using the freezetransfer freeze glass-slide technique [Tassan et al., 2000]. The absorption coefficient of NAP, $a_{\mathrm{NAP}}(\lambda)$, was determined after pigment bleaching with sodium hypochlorite [Ferrari and Tassan, 1999]. Comparison with methanol $(\mathrm{MeOH})$ extraction was conducted, which confirmed that the sodium hypochlorite treatment did not modify the absorption properties of NAP. As it was recently found that all aquatic particles generally show no absorption in the near infrared [Babin and Stramski, 2002], the final estimates of $a_{p}(\lambda)$ and $a_{\mathrm{NAP}}(\lambda)$ were obtained by subtracting the measured values of $a_{p}(750)$ and $a_{\mathrm{NAP}}(750)$ from all the measured spectral values of $a_{p}(\lambda)$ and $a_{\mathrm{NAP}}(\lambda)$, respectively (to be exact, the averages of the measured values between 746 and $750 \mathrm{~nm}$ were subtracted). The phytoplankton absorption coefficient was obtained from the equation:

$$
a_{\phi}(\lambda)=a_{p}(\lambda)-a_{\mathrm{NAP}}(\lambda)
$$

Note that $a_{\phi}(\lambda)$ as determined here includes absorption by all pigments bleached by sodium hypochlorite, which may include phaeopigments associated with particles other than living phytoplankton.

[14] The following expression was fitted to the $a_{\mathrm{NAP}}(\lambda)$ spectra:

$$
a_{\mathrm{NAP}}(\lambda)=\hat{a}_{\mathrm{NAP}}\left(\lambda_{r}\right) \mathrm{e}^{\left(-S_{\mathrm{NAP}}\left(\lambda-\lambda_{r}\right)\right)},
$$

where $\hat{a}_{\mathrm{NAP}}\left(\lambda_{r}\right)$ is the absorption estimate at reference wavelength. The fit was done for data between 380 and 730 $\mathrm{nm}$, excluding the $400-480$ and $620-710 \mathrm{~nm}$ ranges to avoid any residual pigment absorption that might still have been present after sodium hypochlorite treatment. Based on a quality check of each fitted curve, only three spectra were discarded because they contained obvious spectral artifacts. With 36 additional measurements that are missing, we ended up with 348 valid $a_{\mathrm{NAP}}(\lambda)$ spectra and $S_{\mathrm{NAP}}$ values out of 387 stations.

\subsection{Determination of Particle Dry Weight and Pigment Analysis}

[15] To determine the concentration of SPM $\left(\mathrm{g} \mathrm{m}^{-3}\right)$, seawater was filtered under low vacuum onto a preweighed 25-mm glass fiber filter (Whatman, GF/F) until filter clogging $(0.3-31$ were filtered). The filter was rinsed with $25-$ $50 \mathrm{ml}$ of Milli-Q water. This volume is optimal to eliminate salts as much as possible while preventing cell lysis caused by osmotic imbalance. The procedure is described by Van der Linde [1998]. The filter was dried and preserved in a freezer at $-80^{\circ} \mathrm{C}$ until it was weighed less than 2 months later under a dry atmosphere in the laboratory.

[16] For pigment analysis, 200-250 $\mathrm{ml}$ of seawater was filtered onto a $25-\mathrm{mm}$ glass fiber filter (Whatman, GF/F) under low vacuum. The filter was then inserted into a cryotube and kept in liquid nitrogen until analysis in the laboratory less than 3 months later. High-performance liquid chromatography (HPLC) was used as described by Vidussi et al. [1996] to determine liposoluble pigment concentrations. Filters were taken from liquid nitrogen, put into 3-ml vials containing $\mathrm{MeOH}$ and a known amount of $\mathrm{Zn}$ (II) pyropheophorbide $a$ octadecyl ester as internal standard, and stored at $-20^{\circ} \mathrm{C}$ for at least 2 hours. Extraction was completed using a sonication probe and the filtrates were clarified by filtration through glass fiber filters (Whatman, GF/C). The HPLC detection system comprised a diode array spectrophotometer (HP series 1100) set up at $440 \mathrm{~nm}$ for chlorophylls and carotenoids detection and a TSP FL3000 fluorometer for phaeopigment detection. Both detectors were calibrated against authentic standards.

[17] Chl $a$ is here defined as the sum of chlorophyll $a$, divinyl-chlorophyll $a$, chlorophyll $a$ isomer and epimer, and chlorophyllids $a$. TChl is defined as the sum of Chl $a$ and phaeopigments. The total concentration of accessory pigments is defined as the sum of all chlorophylls $b$ and $c$, and all carotenoids. Finally, nonphotosynthetic carotenoids (NPC) include zeaxanthin, alloxanthin, diadinoxanthin, diatoxanthin, $\beta$-carotene, violaxanthin, and neoxanthin. Cell size indices based on pigment composition were derived as by Vidussi et al. [2001]. Proportions in percent of picoplankton $(<2 \mu \mathrm{m})$, nanoplankton $(2-20 \mu \mathrm{m})$, and microplankton $(>20 \mu \mathrm{m})$ were expressed using diagnostic pigments as:

$$
\begin{aligned}
& \text { Picoplankton }(\%) \\
& =\frac{[\text { zeaxanthin }]+[\text { chlorophyll } b+[\text { divinyl }- \text { chlorophyll } b]}{[\text { all diagnostic pigments }]} \times 100,
\end{aligned}
$$

Nanoplankton $(\%)$

$=\frac{[\text { alloxanthin }]+\left[19^{\prime} \text { BFucoxanthin }\right]+\left[19^{\prime} \text { Fucoxanthin }\right]}{[\text { all diagnostic pigments }]} \times 100$,

$\operatorname{Microplankton}(\%)=\frac{[\text { fucoxanthin }]+[\text { peridinin }]}{[\text { all diagnostic pigments }]} \times 100$,

where brackets denote concentration in $\mathrm{mg} \mathrm{m}^{-3}$. These pigment-derived indices might present some limitations, 
discussed by Vidussi et al. [2001], that are linked to (1) the nonunivocal taxonomic significance of certain pigments and (2) the possible presence of certain phytoplankton groups in various size classes. Despite these potential limitations, these pigment-derived indices remain useful and robust tools to extract ecologically relevant information from pigment databases originating from different locations.

\section{Results and Discussion}

\subsection{Variability of Absorption Components}

[18] During the COAST $\ell$ OOC experiment, we encountered a large diversity of coastal waters. We describe qualitatively a few extreme cases to illustrate this diversity. In the mouth of the Rhone River, the suspended white sediments gave the surface waters a turquoise color and a highly turbid character. In the Baltic Sea, the waters were brownish and not as turbid as in the German Bight and in the Marsdiep, where the water was gray and opaque. Finally, at the time when we were there, the waters of the Adriatic Sea were greenish. We will see below that these qualitative observations are consistent with quantitative determinations of water composition and absorption properties. To analyze regional variations, we arranged the data according to the regions as follows: the Mediterranean Sea, Adriatic Sea, Baltic Sea, North Sea, English Channel, and Atlantic Ocean. This rather coarse regional partition was chosen because our sampling grid was not extensive enough to make an analysis at a finer resolution, for example, for individual river plumes.

[19] The variability in the phytoplankton (TChl), NAP (SPM), and CDOM $\left(a_{\mathrm{CDOM}}(443)\right)$ components is illustrated in Figure 2. Overall, our data cover at least three orders of magnitude in TChl and SPM, and two orders of magnitude in $a_{\mathrm{CDOM}}(443)$. In addition to large scatter in the data, the general pattern shows the covariation between these three variables, which means that the occurrence of waters dominated by one or two of the absorbing components is highly improbable. This also means that when one of the components is high, the other two will generally also be relatively high. Nonetheless, the proportions of the three components varied over more than one order of magnitude. Also, regional differences in the proportions of TChl, SMP, and CDOM are illustrated by aggregates of data points, which deviate slightly from the general pattern formed by all the data points.

[20] Table 2 provides the three ratios SPM:TChl, CDOM:TChl, and CDOM:SPM averaged separately for the six investigated regions and for the whole data set. Although variability within each area is large, these averages provide insights into regional differences in terms of optically significant constituents. The Adriatic Sea was found to have low values for all of these ratios, suggesting that these waters were the most phytoplankton-dominated waters and that CDOM was relatively low. As expected from visual observations, the Mediterranean Sea samples showed the largest proportion of particles, both relative to TChl and CDOM. The North Sea samples showed the highest SPM:TChl and CDOM:TChl ratios. The Baltic Sea samples were characterized by low SPM:TChl and high CDOM:SPM ratios, suggesting a relatively low particle content. In addition, and quite surprisingly, the highest
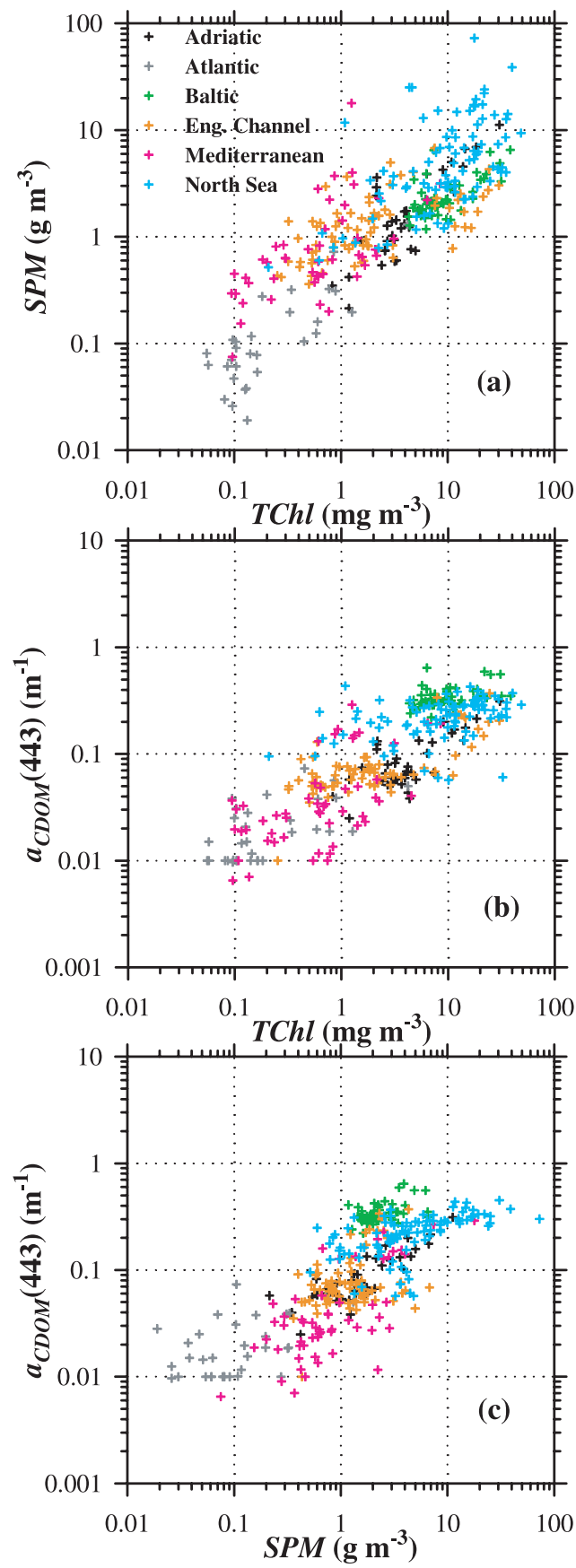

Figure 2. Scatterplots of (a) SPM versus TChl, (b) $a_{\mathrm{CDOM}}(443)$ versus TChl, and (c) $a_{\mathrm{CDOM}}(443)$ versus SPM, for 346, 315, and 315 samples, respectively.

CDOM proportion was generally found in the Atlantic Ocean. As might have been expected, however, it is also in these Case 1 waters where we found the lowest SPM:TChl ratio. Note that because SPM includes phytoplankton, it is not fully independent of TChl (see below).

\subsection{CDOM Absorption}

[21] Figure 3 shows two examples of $a_{\mathrm{CDOM}}(\lambda)$ spectra measured during this study that differ by one order of magnitude. The North Sea sample is smooth and the fit of equation (2) is very good. The Atlantic example represents 
Table 2. Proportions of TChl, SPM, and $\mathrm{CDOM}^{\mathrm{a}}$

\begin{tabular}{|c|c|c|c|c|c|c|c|c|c|c|c|c|c|}
\hline \multirow[b]{2}{*}{ ID } & \multirow[b]{2}{*}{ Area } & \multicolumn{4}{|c|}{ SPM:TChl, $\mathrm{g} \mathrm{mg}^{-1}$} & \multicolumn{4}{|c|}{ CDOM:TChl, $\mathrm{m}^{2} \mathrm{mg}^{-1}$} & \multicolumn{4}{|c|}{ CDOM:SPM, $\mathrm{m}^{2} \mathrm{~g}^{-1}$} \\
\hline & & $N$ & Average & $\mathrm{SD}$ & $\begin{array}{c}\text { Different From } \\
\text { Areas, ID }\end{array}$ & $N$ & Average & $\mathrm{SD}$ & $\begin{array}{c}\text { Different } \\
\text { From Areas, ID }\end{array}$ & $N$ & Average & SD & $\begin{array}{c}\text { Different From } \\
\text { Areas, ID } \\
\end{array}$ \\
\hline $\mathrm{a}$ & Adriatic & 39 & 0.42 & 0.25 & $\mathrm{e}, \mathrm{f}$ & 39 & 0.59 & 0.27 & b,c,e,f & 39 & 1.67 & 1.00 & $\mathrm{~b}, \mathrm{~d}, \mathrm{f}$ \\
\hline $\mathrm{b}$ & Atlantic & 33 & 0.41 & 0.28 & $e, f$ & 20 & 1.91 & 1.24 & $\mathrm{a}, \mathrm{d}$ & 20 & 5.80 & 3.74 & $\mathrm{a}, \mathrm{c}, \mathrm{d}, \mathrm{e}, \mathrm{f}$ \\
\hline $\mathrm{c}$ & Baltic & 54 & 0.67 & 0.19 & $e, f$ & 54 & 1.58 & 0.49 & $\mathrm{a}, \mathrm{f}$ & 54 & 2.41 & 0.58 & $\mathrm{~b}$ \\
\hline d & Channel & 81 & 0.53 & 0.50 & $e, f$ & 72 & 1.01 & 0.46 & $\mathrm{~b}, \mathrm{e}, \mathrm{f}$ & 72 & 2.71 & 1.72 & $\mathrm{a}, \mathrm{b}, \mathrm{e}$ \\
\hline e & Mediterranean & 51 & 1.48 & 3.04 & $a, b, c, d$ & 45 & 1.70 & 1.69 & $\mathrm{a}, \mathrm{d}$ & 45 & 1.97 & 1.60 & $\mathrm{~b}, \mathrm{~d}$ \\
\hline$f$ & North Sea & 88 & 1.10 & 0.66 & $\mathrm{a}, \mathrm{b}, \mathrm{c}, \mathrm{d}$ & 85 & 2.16 & 2.75 & $\mathrm{a}, \mathrm{c}, \mathrm{d}$ & 85 & 2.46 & 2.54 & $a, b$ \\
\hline$\ldots$ & all & 346 & 0.81 & 1.29 & $\ldots$ & 315 & 1.52 & 1.70 & $\ldots$ & 315 & 2.56 & 2.14 & $\ldots$ \\
\hline
\end{tabular}

${ }^{a}$ Average values were compared for the differences between the investigated regions using a Fisher PLSD test. These values were considered significantly different when $p<0.05$. The column "different from areas (ID)" shows the regions identified through ID, which are significantly different from a given region listed in the column "area." Normality of distributions was verified successfully using a Komolgorov-Smirnov test [Sokal and Rohlf, 1981]. CDOM concentration is represented by $a_{\mathrm{CDOM}}(443)$.

one of the most noisy spectra considered in this analysis. Besides the apparent random noise, this sample shows a strong temperature-related artifact at $\lambda>725 \mathrm{~nm}$. This was caused by a temperature difference between the sample and the reference. Nevertheless, the exponential fit seems to be reliable, especially between 350 and $500 \mathrm{~nm}$.

[22] As mentioned above, the magnitude of the $a_{\mathrm{CDOM}}(\lambda)$ spectrum varied by ca. two orders of magnitude during COAST $\ell$ OOC surveys (Figure 2). At regional scales, it varied much less, except in the Mediterranean Sea where it covered nearly the entire range of the observed variability. Figure $4 \mathrm{a}$ illustrates the overall variations in $S_{\mathrm{CDOM}}$. The average value based on all data was $0.0176 \mathrm{~nm}^{-1}$ and the standard deviation $0.0020 \mathrm{~nm}^{-1}$. Table 3 provides the $S_{\mathrm{CDOM}}$ statistics for each region. Although the overall variability was very low with a coefficient of variation of $11.4 \%$, there were significant differences in $S_{\mathrm{CDOM}}$ between the regions as confirmed by an ANOVA $(p<0.0001)$. Based on a comparison of the average values, the regions can be divided into two groups: the Adriatic and Baltic Seas with relatively high slopes around $0.019 \mathrm{~nm}^{-1}$, and all other regions with smaller slopes around $0.017 \mathrm{~nm}^{-1}$. Our estimate of average $S_{\mathrm{CDOM}}$ for the Atlantic is higher than the values reported by Bricaud et al. [1981], Blough et al. [1993], and Barnard et al. [1998] for Case 1 waters (around $0.014 \mathrm{~nm}^{-1}$ ), but within the range or smaller than those reported by Roesler et al. [1989], Nelson and Guarda [1995], Vodacek et al. [1997], and Nelson et al. [1998]. Our Baltic Sea average value is nearly identical to that found previously in the southern Baltic Sea [Ferrari and Dowell, 1998; Kowalczuk, 1999]. In the southern Bight of the North Sea and in the English Channel, Warnock et al. [1999] found an average $S_{\mathrm{CDOM}}$ between 0.016 and 0.017 for a spectral range similar to the one in the present study, which is very close to what we found in this region.

[23] Figure 5 shows the scatterplot of $S_{\mathrm{CDOM}}$ as a function of $a_{\mathrm{CDOM}}(443)$. It does not reveal any clear inverse relationship as suggested by Carder et al. [1989] and others, but shows a pattern similar to that found by Vodacek et al. [1997] with larger variability in $S_{\mathrm{CDOM}}$ at smaller values of $a_{\mathrm{CDOM}}(443)$. This pattern may result from the experimental random error, which suggests that the actual variability of $S_{\mathrm{CDOM}}$ may in fact be smaller than our data show.

[24] Although some differences seem to occur between the regions, the overall variability we observed in $S_{\mathrm{CDOM}}$ is rather small given the large diversity of the waters exam- ined. One advantage of the present study is that all the measurements and analyses were done using exactly the same procedures for all samples. The relatively broad range in the $S_{\mathrm{CDOM}}$ values reported in the literature may be partly due to the fact that various methods were used to measure $a_{\mathrm{CDOM}}(\lambda)$ and to derive $S_{\mathrm{CDOM}}$ (optical setup, spectral range, baseline correction, fitting procedure). For instance, an inappropriate use of the $\lambda^{-1}$ dependent baseline correction results in an underestimation of $S_{\mathrm{CDOM}}$. Bricaud et al. [1981] had introduced this correction approach for samples still containing small particles after filtration onto $\mathrm{GF} / \mathrm{C}$ (Whatman) glass fiber filters. Our samples did not contain such particles after filtration onto membrane filters with $0.22-\mu \mathrm{m}$ pore size. Also, it has been suggested that $S_{\mathrm{CDOM}}$ decreases with increasing $\lambda$ between the UV and the visible range [e.g., Warnock et al., 1999]. We note, however, that the common use of a linear fit on log-transformed $a_{\mathrm{CDOM}}(\lambda)$ data to determine $S_{\mathrm{CDOM}}$ gives more statistical weight to relatively low values in the visible range than does the nonlinear regression applied in this study. The linear approach may thus lead to smaller values of $S_{\mathrm{CDOM}}$.

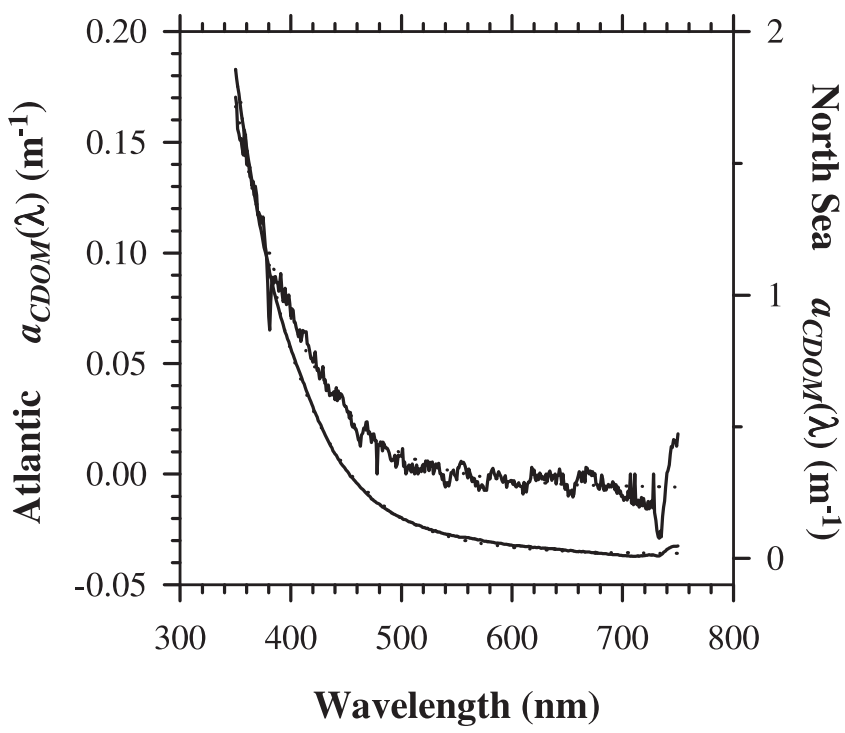

Figure 3. Examples of the measured CDOM absorption spectra (solid lines) and the corresponding exponential fits (dotted lines) for the Atlantic (upper curves, $y$ axis on the left) and the North Sea (lower curves, $y$ axis on the right). 

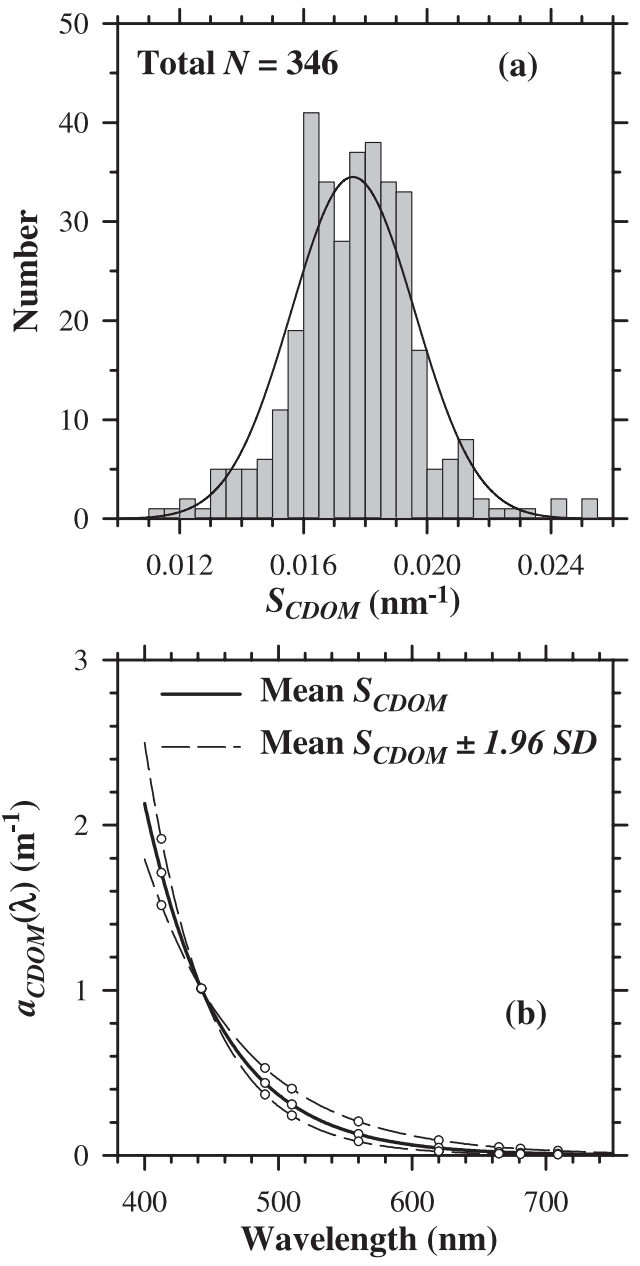

Figure 4. (a) Frequency distribution of the exponential slope, $S_{\mathrm{CDOM}}$, of the CDOM absorption spectrum. The Gaussian curve is also displayed to illustrate the normal distribution that corresponds to the average values of $S_{\mathrm{CDOM}}$ $\left(0.0176 \mathrm{~nm}^{-1}\right)$ and the standard deviation $\left(0.002 \mathrm{~nm}^{-1}\right)$. The integrals of the observed and calculated distributions are equal. (b) The $a_{\mathrm{CDOM}}(\lambda)$ spectra calculated from equation (2) with $a_{\mathrm{CDOM}}\left(\lambda_{r}\right)=1, \lambda_{r}=443 \mathrm{~nm}$, and $S_{\mathrm{CDOM}}$ $=0.0176 \mathrm{~nm}^{-1}$ (solid line: the overall average found in the present study). Spectra are also shown for $S_{\mathrm{CDOM}}=0.0176$ $\pm 1.96 \mathrm{SD} \mathrm{nm}^{-1}$, where $\mathrm{SD}=0.0020 \mathrm{~nm}^{-1}$ (dashed lines; see Table 3$). a_{\mathrm{CDOM}}(\lambda)$ at nine wavelengths representing spectral channels of the MERIS sensor (launched by the European Space Agency on the Envisat platform on 1 March 2002) are indicated as open circles.

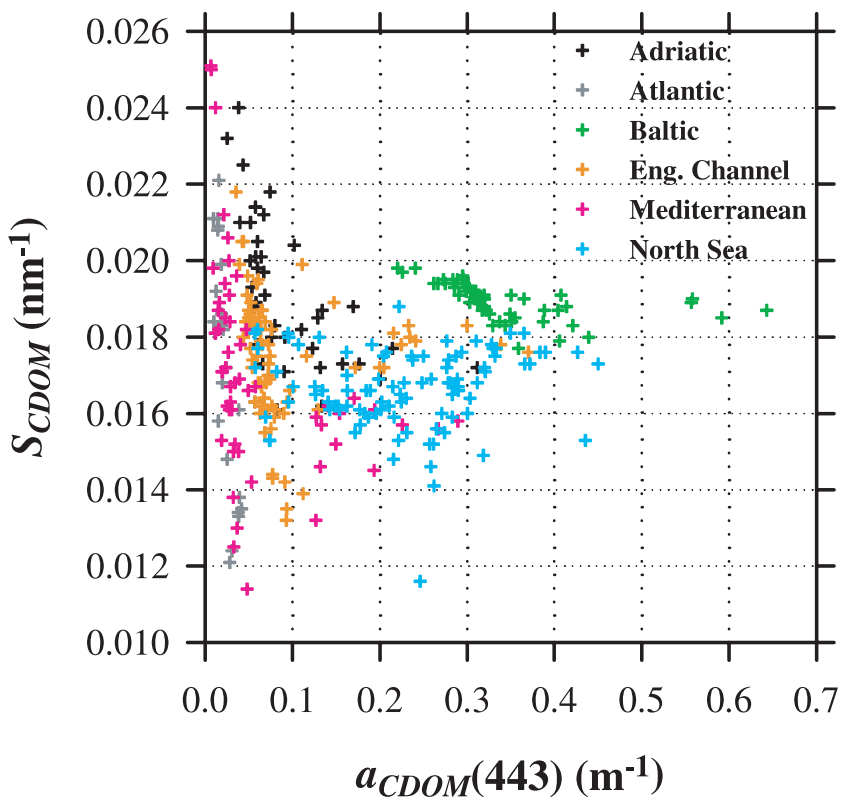

Figure 5. Scatterplot of $S_{\mathrm{CDOM}}$ as a function of $a_{\mathrm{CDOM}}(443)$.

[25] Our results show that, on average, CDOM absorption could be expressed as:

$$
a_{\mathrm{CDOM}}(\lambda)=a_{\mathrm{CDOM}}(443) \mathrm{e}^{(-0.0176(\lambda-443))} .
$$

Figure $4 \mathrm{~b}$ illustrates this equation and the range that comprises $95 \%$ of COAST $\ell$ OOC samples, considering the average $S_{\mathrm{CDOM}}$ value \pm 1.96 times the standard deviation. At $412 \mathrm{~nm}$ where the magnitude of CDOM absorption is significant, the ratio $a_{\mathrm{CDOM}}(412): a_{\mathrm{CDOM}}(443)$ is, on average, 1.71 , and in extreme cases 1.51 or 1.91 . At $560 \mathrm{~nm}$ where the magnitude of CDOM absorption is low, the ratio $a_{\mathrm{CDOM}}(560): a_{\mathrm{CDOM}}(443)$ is, on average, 0.13 , and in extreme cases 0.08 or 0.20 .

\subsection{Phytoplankton Absorption}

[26] The statistical analysis conducted by Bricaud et al. [1995] in Case 1 waters revealed that the chlorophyllspecific absorption coefficient $a_{\phi}^{*}(\lambda)$ and the blue-to-red absorption ratio generally decrease when TChl increases as a result of increasing pigment packaging and decreasing the proportion of accessory pigments. These trends reflect the changes in phytoplankton photoacclimation and species

Table 3. Overall and Site-by-Site Statistics for the Spectral Slope of the $a_{\mathrm{CDOM}}(\lambda)$ Spectrum, $S_{\mathrm{CDOM}}\left(\mathrm{nm}^{-1}\right)^{\mathrm{a}}$

\begin{tabular}{|c|c|c|c|c|c|c|c|c|}
\hline ID & Area & $N$ & $\begin{array}{c}\text { Minimum } \\
\text { Value }\end{array}$ & $\begin{array}{l}\text { Maximum } \\
\text { Value }\end{array}$ & $\begin{array}{l}\bar{S}_{\mathrm{CDOM}}, \\
\text { Average }\end{array}$ & $\begin{array}{c}\sigma_{S_{\mathrm{CDOM}}}, \text { Standard } \\
\text { Deviation }\end{array}$ & $\begin{array}{c}\text { Variation } \\
\text { Coefficient, \% }\end{array}$ & $\begin{array}{c}\text { Different From } \\
\text { Areas, ID } \\
\end{array}$ \\
\hline $\mathrm{a}$ & Adriatic & 39 & 0.0161 & 0.0240 & 0.0192 & 0.0020 & 10.1 & $\mathrm{~b}, \mathrm{~d}, \mathrm{e}, \mathrm{f}$ \\
\hline b & Atlantic & 24 & 0.0121 & 0.0221 & 0.0172 & 0.0030 & 17.7 & $\mathrm{a}, \mathrm{c}$ \\
\hline $\mathrm{c}$ & Baltic & 57 & 0.0177 & 0.0198 & 0.0190 & 0.0005 & 2.4 & $\mathrm{~b}, \mathrm{~d}, \mathrm{e}, \mathrm{f}$ \\
\hline d & Channel & 75 & 0.0132 & 0.0218 & 0.0174 & 0.0016 & 9.2 & $\mathrm{a}, \mathrm{c}$ \\
\hline $\mathrm{e}$ & Mediterranean & 54 & 0.0114 & 0.0251 & 0.0170 & 0.0028 & 16.2 & $a, c$ \\
\hline $\mathrm{f}$ & North Sea & 96 & 0.0116 & 0.0188 & 0.0167 & 0.0004 & 2.3 & $a, c$ \\
\hline$\ldots$ & all & 345 & 0.0114 & 0.0251 & 0.0176 & 0.0020 & 11.4 & $\ldots$ \\
\hline
\end{tabular}

${ }^{a}$ Average values were compared for differences between the investigated regions using a Fisher PLSD test. These values were considered significantly different when $p<0.05$. The column "different from areas (ID)" shows the regions identified through ID, which are significantly different from a given region listed in the column "area." Normality of distributions was verified successfully using a Komolgorov-Smirnov test. 
composition that occur when going from typical oligotrophic to typical eutrophic systems at low and medium latitudes [see for instance Morel and Berthon, 1989; Claustre, 1994; Babin et al., 1996; Allali et al., 1997; Trees et al., 2000]. In typical oligotrophic waters, the euphotic zone is thicker than the mixed layer. According to the model proposed by Babin et al. [1996], this situation gives rise to two vertically distinct habitats. Both habitats are mostly inhabited by picoplankton. The upper one is delimited by the sea surface and the pycnocline, and is characterized by high light and low nutrient concentrations. Cyanobacteria having a small cell size (low packaging effect) and a high zeaxanthin-to-chlorophyll $a$ ratio are often dominant. These microorganisms therefore exhibit very high $a_{\phi}^{*}(\lambda)$, especially in the blue [see Babin et al., 1996; Allali et al., 1997]. The deeper habitat is delimited by the pycnocline and below by the disappearance of light. It is characterized by low light levels and high nutrients. Prochlorophytes and picoeucaryotes are generally dominant. These organisms are small and contain significant amounts of accessory pigments for light harvesting. In this layer $a_{\phi}^{*}(\lambda)$ is therefore high but less than in the upper habitat because of high intracellular pigment concentrations which lead to some packaging effect [Allali et al., 1997]. TChl is typically very low in the upper habitat (often $<0.1$ $\left.\mathrm{mg} \mathrm{m}^{-3}\right)$ and significantly higher in the lower one $(>0.3$

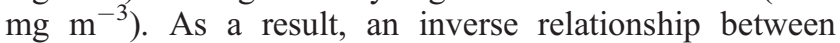
$a_{\phi}^{*}(\lambda)$ and TChl can be observed at the vertical scale in oligotrophic waters.

[27] In contrast, eutrophic waters, where TChl is generally high $\left(>1 \mathrm{mg} \mathrm{m}^{-3}\right)$, are characterized by a mixed layer that often extends deeper than the euphotic zone. This configuration gives rise to a single phytoplankton habitat delimited by the sea surface and the pycnocline, where nutrients are abundant. Phytoplankton growth cannot occur beneath the pycnocline because light is too low. The phytoplankton community is generally dominated by large cells (e.g., diatoms, dinoflagellates). They experience large variations in irradiance when traveling up and down within the mixed layer, but are acclimated to moderate light as a result of the photoacclimation kinetics [Lewis et al., 1984]. Because larger phytoplankton do not contain lots of accessory pigments compared with picoplankton and because of a strong packaging effect due to large cell size, $a_{\phi}^{*}(\lambda)$ is generally very low in such systems [see the discussion of Bricaud et al., 1995].

[28] A gradual change from oligotrophic to eutrophic conditions would explain the inverse relationship between $a_{\phi}^{*}(\lambda)$ and TChl at large horizontal scales [Bricaud et al., 1995]. Moreover, both trends at vertical and horizontal scales merge into a general trend for Case 1 waters. The global relationship between $a_{\phi}^{*}(\lambda)$ and TChl found in Case 1 waters thus relies upon the ecophysiological transition that occurs between eutrophic and oligotrophic systems, with the associated vertical changes in the physical and chemical conditions. This scheme may not necessarily hold in coastal waters because of various hydrodynamical events such as upwelling, advection, fronts, freshwater inputs, as well as the complexity of light field conditions. Here the analysis of our $a_{\phi}(\lambda)$ data is conducted with the Case 1 water statistics of Bricaud et al. [1995] (hereafter denoted as B95) as a reference.
[29] Figure 6 shows representative examples of $a_{\phi}(\lambda)$ normalized to TChl, $a_{\infty}^{*}(\lambda)$, which illustrate variations in the spectral shape and magnitude relative to TChl, among the investigated areas. Our spectral $a_{\infty}^{*}(\lambda)$ are displayed together with the spectra estimated as a function of the corresponding TChl according to $B 95\left(\hat{a}_{\phi}^{*}(\lambda)\right)$ In the present study, the highest blue-to-red ratios were observed at the lowest TChl in the Atlantic and the Mediterranean Sea, which are consistent with the $B 95$ statistics (Figures $6 \mathrm{~b}$ and $6 \mathrm{e})$. The general spectral shape of these two $a_{\phi}^{*}(\lambda)$ spectra is rather well reproduced by the $B 95$ curves. But high blue-tored ratios were also observed in the North Sea and the Adriatic Sea (Figures 6a and 6f) where TChl was generally very high. In the North Sea, the high $a_{\phi}^{*}(\lambda)$ values between 400 and $410 \mathrm{~nm}$ strongly suggest a significant contribution by phaeopigments, similar to previous observations in Case 2 waters [Roesler et al., 1989; Babin et al., 1993]. The lowest blue-to-red ratios were observed at high TChl in the Baltic Sea (Figure 6c), which is also consistent with the prediction from the $B 95$ statistics. Differences in the magnitude of our $a_{\phi}^{*}(\lambda)$ and those predicted by $B 95$ across the entire spectrum are especially large in the English Channel, but are also significant in the Baltic Sea and the North Sea.

[30] In Figure 7, we plotted $a_{\phi}(\lambda)$ as a function of TChl and as a function of Chl $a$ (all forms of chlorophyll $a$, no phaeopigments) at 412, 443, and $676 \mathrm{~nm}$. We also illustrated with curves of the $B 95$ statistics (in terms of $a_{\phi}(\lambda)$ instead of $a_{\phi}^{*}(\lambda)$ ). At $443 \mathrm{~nm}$ (Figure 7b), most values measured in the Atlantic and Mediterranean Sea fall within the confidence intervals of the $B 95$ statistics [see Bricaud et al., 1998]. Data from the Baltic Sea, Adriatic Sea, and North Sea also fall within these confidence intervals. However, the Baltic and Adriatic data are generally above the B95 regression line and the North Sea data are below. Most $a_{\phi}(443)$ values from the English Channel are above the $B 95$ regression line, and many data points from this region are found outside the upper confidence interval of $B 95$ when TChl $<2.5 \mathrm{mg} \mathrm{m}^{-3}$.

[31] Differences between our values of $a_{\phi}(443)$ and those predicted by the $B 95$ regression can be explained by differences in pigment composition and cell size distribution, relative to what is typically found at similar TChl in Case 1 waters [Bricaud et al., 2000]. Figure 8a shows the concentration of accessory pigments as a function of $\mathrm{Chl} a$. The parameter values of the power law fit to these data are close to those reported recently for a large pigment data set that includes both Case 1 and Case 2 waters [Trees et al., 2000] (see also caption of Figure 8). Only the Baltic and Adriatic data points seem to depart slightly from our regression line; these data show higher values. If the concentration of accessory pigments is plotted as a function of TChl (Figure 8b), then data points are scattered mostly below the regression line mentioned above (see figure caption), which is most pronounced for the North Sea. This is because (1) the accessory pigments were in general poorly correlated with phaeopigments, (2) the ratio of accessory pigments to phaeopigments was lowest in the North Sea (Figure 8c), and (3) the ratio of Chl $a$ to TChl was lowest in the North Sea (Figure 9). This explains why most North Sea data points are below $B 95$ statistics in the relationship between $a_{\phi}(443)$ and TChl (Figure 7b). This difference is consistently more pronounced at $676 \mathrm{~nm}$ (Figure 7c) 

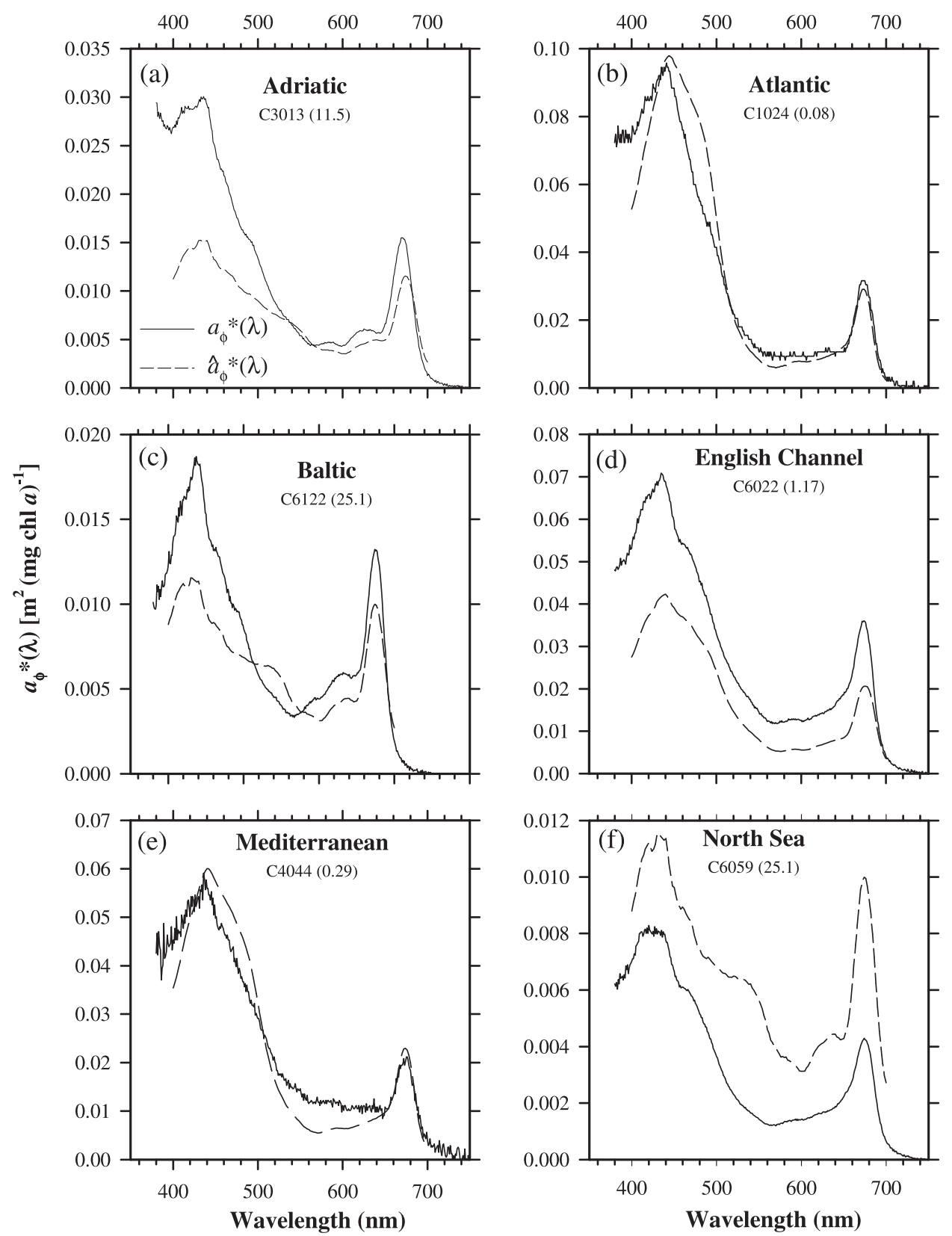

Figure 6. Examples of phytoplankton absorption spectra (solid lines) for each investigated region: (a) Adriatic Sea, (b) Atlantic, (c) Baltic Sea, (d) English Channel, (e) Mediterannean Sea, and (f) North Sea. The station number beginning with the character $\mathrm{C}$ and the TChl value (the number in parenthesis) are given for each example. For comparison, the spectra derived from the statistics of Bricaud et al. [1995] (dashed lines) are shown for the same TChl value. Note that the y-axis scale varies among the panels.

because phaeopigment weight-specific absorption is much lower than that of chlorophyll $a$ in the red [Lorenzen and Downs, 1986; Cleveland and Perry, 1994]. Conversely, at $412 \mathrm{~nm}$ (Figure 7a) where phaeopigment absorption is maximal [Vernet and Lorenzen, 1987; Roesler et al., 1989], $a_{\phi}(412)$ as a function of TChl in the North Sea is in agreement with the $B 95$ statistics. When $a_{\phi}(\lambda)$ is plotted as a function of Chl $a$ (Figures $7 \mathrm{~d}-7 \mathrm{f}$ ), trends are consistently reversed: the agreement between our observations in the North Sea and 895 statistics is poor in the blue and improves toward the red. In other regions, data points in the $a_{\phi}(\lambda)$ versus TChl and $a_{\phi}(\lambda)$ versus Chl $a$ relation- ships are also affected by phaeopigments, but to a much lesser extent (Figure 7).

[32] In Figure 10, NPC concentration is plotted as a function of Chl $a$ and TChl. In both cases, the Adriatic data points are above the general trend with the NPC-to-Chl $a$ (and TChl) ratio nearly as high as in oligotrophic waters. The carotenoids mostly responsible for this high NPC-toChl $a$ ratio were diadinoxanthin and diatoxanthin probably belonging to the diatom Cerataulina pelagica that dominated the phytoplankton community in most Adriatic Sea samples (G. Johnsen, unpublished data, 1999). This peculiar pigment composition is responsible for the high blue-to-red 

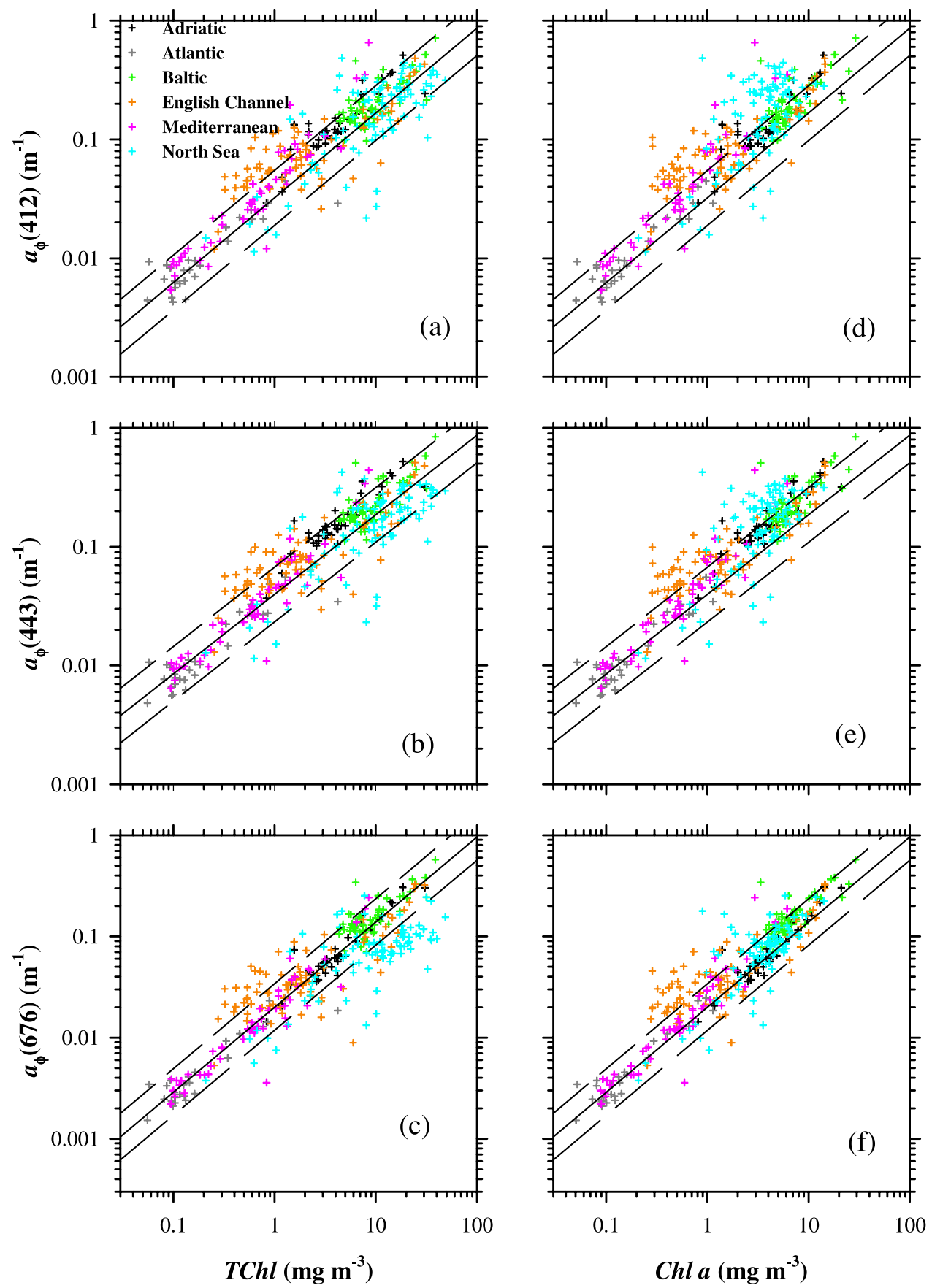

Figure 7. Scatterplots of the phytoplankton absorption coefficient at 412, 443 and $676 \mathrm{~nm}$ as a function of TChl $(\mathrm{a}-\mathrm{c})$ and $\mathrm{Chl}$ a $(\mathrm{d}-\mathrm{f})$. The statistics of Bricaud et al. [1995] is illustrated by the three lines: the solid one represents the average $a_{\phi}(\lambda)$ versus TChl or Chl a relationship, and the dashed ones represent the $90 \%$ confidence intervals.

ratio observed in $a_{\phi}(\lambda)$ in the Adriatic Sea (Figure 6a), and explains why the Adriatic $a_{\phi}(\lambda)$ values are above the $B 95$ statistics at 412 and $443 \mathrm{~nm}$, and not at $676 \mathrm{~nm}$ when plotted as a function of TChl or Chl $a$ (Figure 7). NPC is also higher in the Baltic Sea compared with the North Sea and English Channel at similar Chl $a$ and TChl (Figure 10). This may only partly explain why $a_{\phi}(\lambda)$ in the Baltic Sea is above the $B 95$ statistics in Figure 7, because this is the case at $676 \mathrm{~nm}$ as well, i.e., the blue-to-red ratio was not especially high in the Baltic.
[33] Pigment composition does not explain why the $a_{\phi}(\lambda)$ values in the English Channel are significantly above the $B 95$ statistics in Figure 7. Therefore phytoplankton cell size may be the responsible factor. The $B 95$ statistics imply that the cell size generally increases with increasing TChl, which would reflect the shift from picoplankton-dominated communities in oligotrophic waters to microplankton-dominated communities in eutrophic waters. Figure 11 shows proportions of picoplankton, nanoplankton, and microplankton as a function of TChl, as derived from pigment composition 

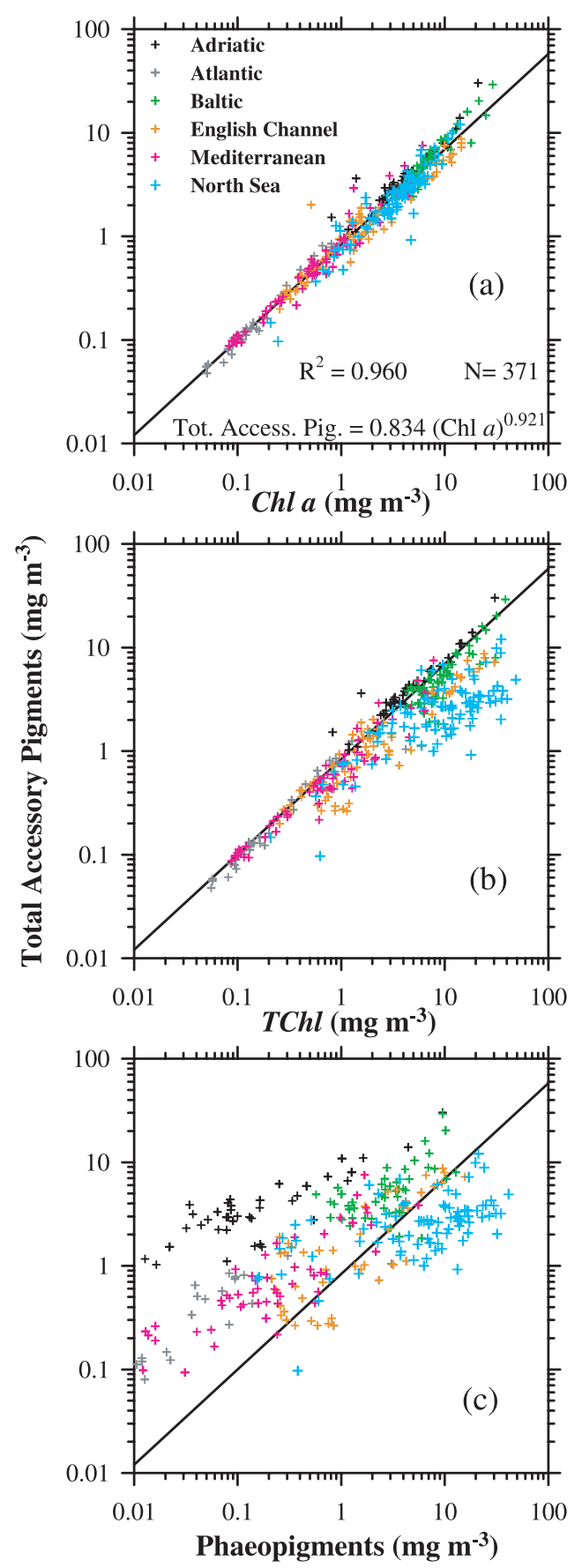

Figure 8. Scatterplots of the concentration of total accessory pigments (see text for definition) as a function of (a) Chl $a$, (b) TChl, and (c) phaeopigments concentration. The result of a linear regression performed on logtransformed values of total accessory pigments and Chl $a$ is illustrated in Figure 8a. The regression equation shown in Figure $8 \mathrm{a}$ is applied and illustrated in panels Figures $8 \mathrm{~b}$ and $8 \mathrm{c}$ by using TChl and phaeopigments, respectively, as independent variable instead of $\mathrm{Chl} a$. The parameter values for the best fit of the power law function are close to those recently reported by Trees et al. [2000]. Although, in contrast to this study, the Trees et al. definition of accessory pigments includes phaeopigments, their statistics were unaffected by low levels of these pigments in their data set. (see section 2). It clearly indicates that picoplankton dominated most English Channel samples when TChl $<2.5 \mathrm{mg} \mathrm{m}^{-3}$, and many of the Baltic Sea samples. Consistently, nanoplankton and microplankton are relatively low in the English Channel and the Baltic Sea, respectively, compared with other regions at similar TChl ranges. The small size of phytoplankton cells in the English Channel, and to some extent, in the Baltic Sea would result in a low packaging effect [Bricaud and Morel, 1986] and explain why $a_{\phi}(\lambda)$ values are above the $B 95$ statistics in Figure 7.

[34] Overall, most of the $a_{\phi}(\lambda)$ values that we observed in the COAST $\ell$ OOC data set were contained within the confidence intervals of the $a_{\phi}(\lambda)$ versus TChl statistics of Bricaud et al. [1995] established for Case 1 water. The $a_{\phi}(\lambda)$ parameterization is more robust when performed as a function of TChl rather than Chl $a$, especially in the blue spectral region (Figure 7). Significant departures from the

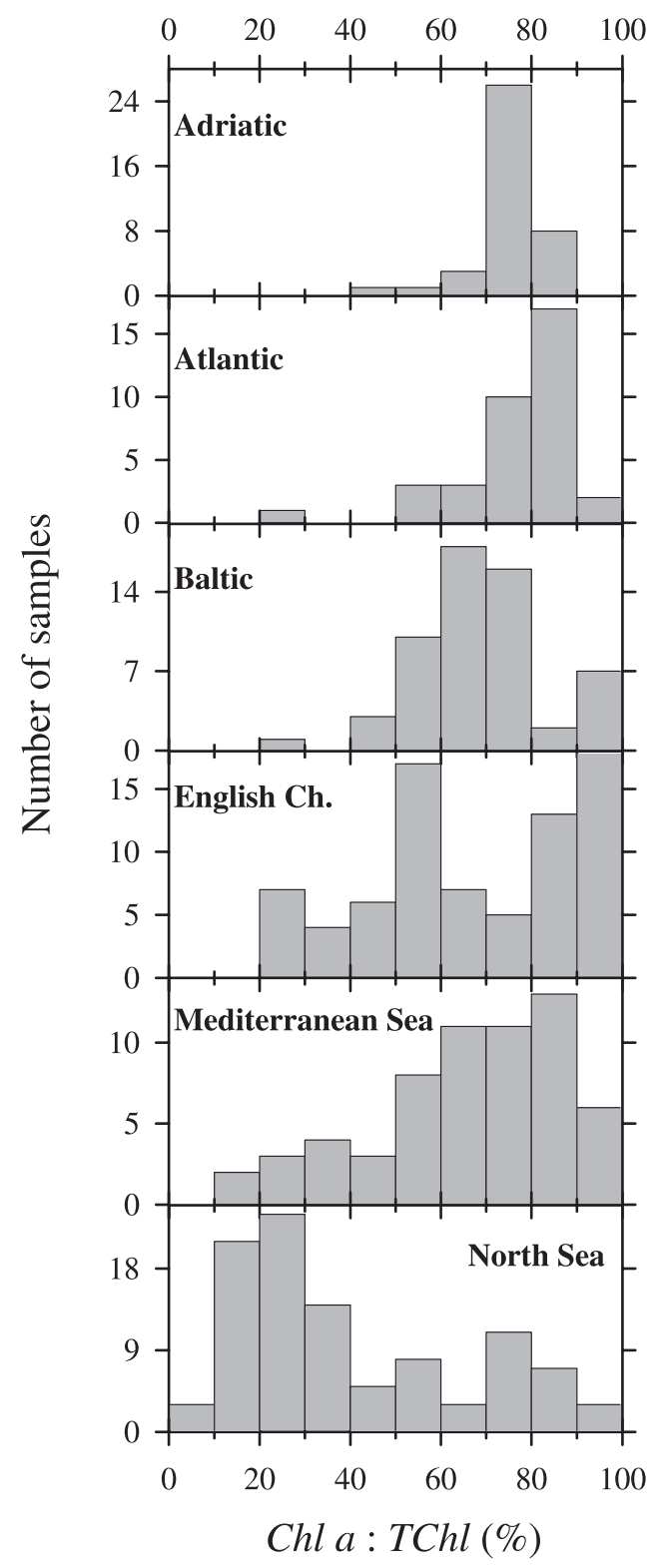

Figure 9. Frequency distributions of the $\mathrm{Chl} a$ :TChl ratio (\%) in different regions. 

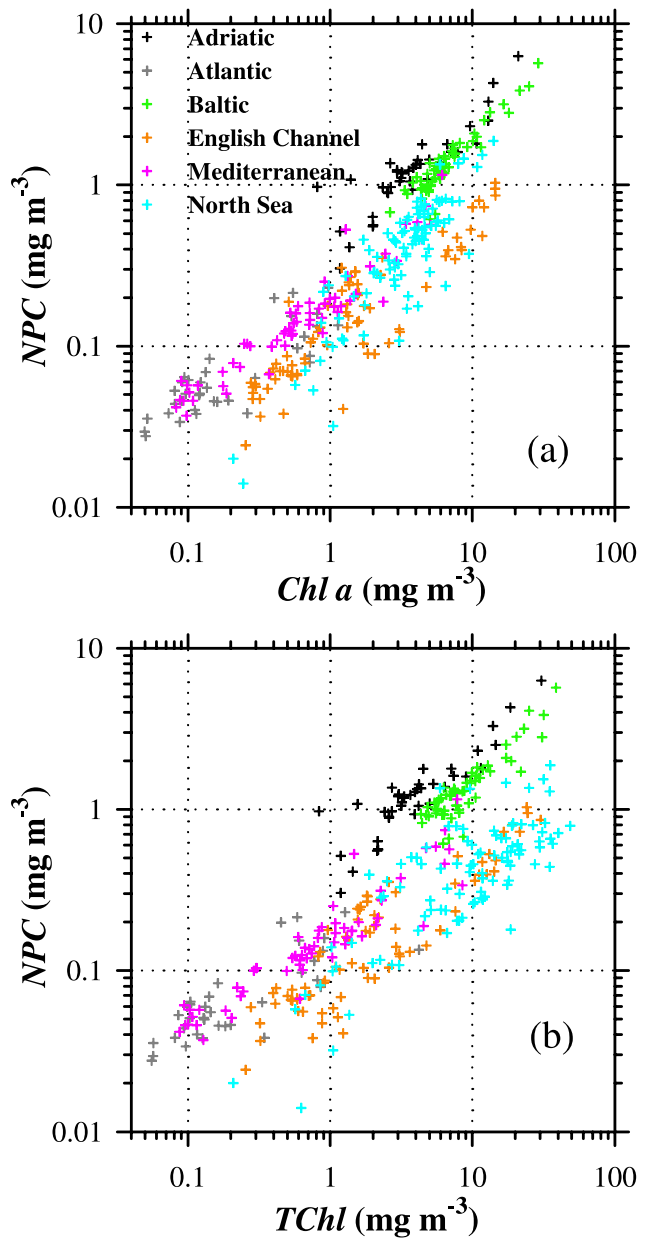

Figure 10. Scatterplots of the concentration of nonphotosynthetic pigments as a function of (a) Chl $a$ and (b) TChl.

B95 statistics were nevertheless found, which can be explained in terms of pigment composition and/or cell size. Regional departures from an average parameterization are also to be expected in Case 1 waters as mentioned by Bricaud et al. [1995, 1998], but they may occur more often in coastal waters. In particular, the occurrence of high phaeopigment concentrations in coastal waters may lead to large and hardly predictable variation in $a_{\phi}(\lambda)$. Furthermore, we observed more general differences between the trends in our $a_{\phi}(\lambda)$ data and the B95 statistics. Figure 12 shows the relationship we found between $a_{\phi}(443)$ and $a_{\phi}(676)$, and between the ratio $a_{\phi}(443): a_{\phi}(676)$ and Chl $a$ (and TChl), together with the corresponding relationships predicted by the $B 95$ statistics. We can clearly see that because of the high blue-to-red absorption ratio, the North Sea and Adriatic Sea samples tend to be separated from other data. In addition, our data in general diverge from the B95 statistics at high $a_{\phi}(\lambda)$ and high TChl. Thus the application of the B95 statistics in coastal waters may often lead to important errors in the estimation of $a_{\phi}(\lambda)$ from TChl and vice versa.

\subsection{NAP Absorption}

[35] Figure 13 shows six examples of $a_{\text {NAP }}(\lambda)$ spectra to illustrate representative spectral signatures we observed during COAST $\ell$ OOC campaigns. These spectra are shown together with an exponential fit (equation (4)). Most (ca. $80 \%) a_{\mathrm{NAP}}(\lambda)$ spectra fitted an exponential function very well (equation (4)) as illustrated in Figure 13a. Residual absorption by pigments resulting from incomplete bleaching was, however, often observed in regions of chlorophyll $a$ absorption bands, i.e., around 430 and $675 \mathrm{~nm}$. Because we excluded the 400-480 and 620-710 $\mathrm{nm}$ ranges when fitting the exponential function, this residual absorption had no impact on the determination of the parameters $\hat{a}_{\mathrm{NAP}}\left(\lambda_{r}\right)$ and $S_{\mathrm{NAP}}$ (equation (4)). It can be seen in Figure $13 \mathrm{~b}$ how well
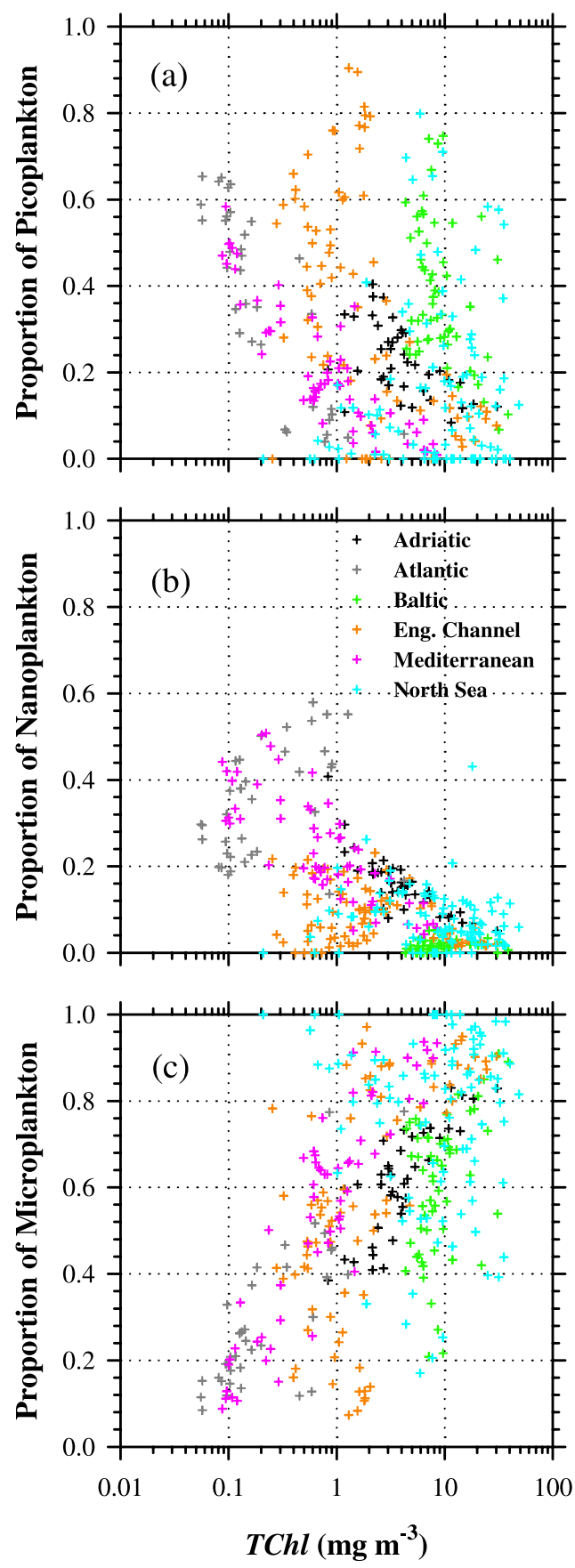

Figure 11. Scatterplots of (a) picoplankton, (b) nanoplankton, and (c) microplankton proportions (see definition in text) as a function of TChl. 

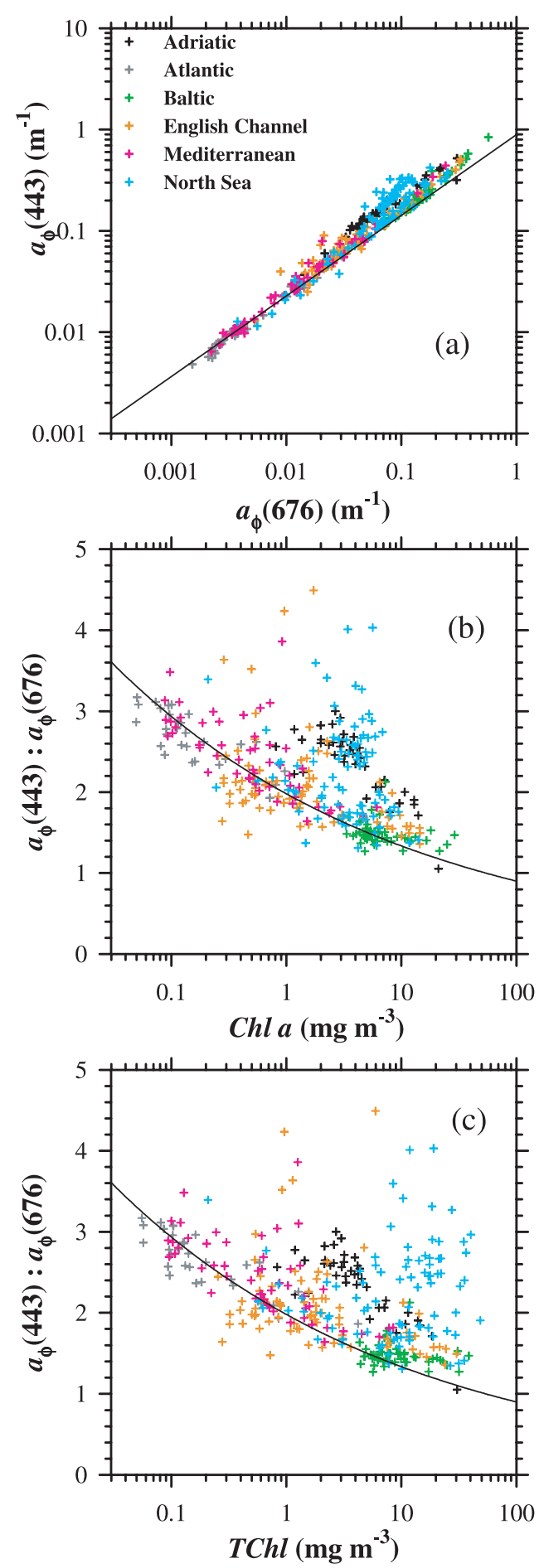

Figure 12. Scatterplots of (a) $a_{\phi}$ (443) versus $a_{\phi}(676)$, (b) $a_{\phi}(443): a_{\phi}(676)$ versus Chl $a$, and (c) $a_{\phi}(443): a_{\phi}(676)$ versus TChl. The Bricaud et al. [1995] statistics is illustrated in each panel as a solid line.

the exponential function fits the data and isolates residual pigment absorption.

[36] In Figures $13 \mathrm{c}$ and 13d, examples are shown of spectral features in the $450-550 \mathrm{~nm}$ region which most likely can be attributed to iron oxides associated with the presence of minerals (G. M. Ferrari, unpublished data,
2001). The fit with an exponential function is degraded, although it reproduces the observed overall increase in absorption toward the UV. The resulting $S_{\mathrm{NAP}}$ values are within the range of values found in other regions (Table 4).

[37] In the Baltic Sea, we systematically observed spectra with the shape shown in Figure 13e, where the exponential fit is good at $\lambda>440 \mathrm{~nm}$. At shorter wavelengths, the measured values drop below the fitted line. Because this spectral signature was observed even when no residual pigment absorption occurred in the red, we do not believe it is due to pigments. Therefore for the Baltic Sea data, we fitted the exponential function over the 440-620 and 710$730 \mathrm{~nm}$ ranges to derive $\hat{a}_{\mathrm{NAP}}\left(\lambda_{r}\right)$ and $S_{\mathrm{NAP}}$. We found $S_{\mathrm{NAP}}$ values close to those found in other regions. Finally, we observed a few $a_{\mathrm{NAP}}(\lambda)$ spectra in the Mediterranean Sea with a characteristic, rather unusual absorption feature in the $600-700 \mathrm{~nm}$ range (Figure 13f). It is unlikely that this feature is due to some pigment because the hypochlorite oxidation is efficient for liposoluble as well as hydrosoluble pigments [Ferrari and Tassan, 1999]. The origin of this absorption feature remains an open question.

[38] Overall, the exponential function fitted the vast majority of $a_{\mathrm{NAP}}(\lambda)$ spectra well. It is obvious that $a_{\mathrm{NAP}}(\lambda)$ spectra often have an exponential spectral shape similar to that of $a_{\mathrm{CDOM}}(\lambda)$, which suggests that these two components may share some common chromophores. It is interesting to note that even in the case of mineral-dominated samples (e.g., Figures $13 \mathrm{c}$ and $13 \mathrm{~d}$ ), our $a_{\mathrm{NAP}}(\lambda)$ spectra were also close to an exponential function, although spectral features typical of iron oxides may cause some deviation from the exponential fit. Moreover, Bowers et al. [1996] observed a CDOM-like spectral shape in measurements of combusted (mineral) particles.

[39] The range of $S_{\mathrm{NAP}}$ values derived in this study was relatively narrow (Table 4 and Figure 14a). The overall average value was $0.0123 \mathrm{~nm}^{-1}$ with a coefficient of variation of $10.3 \%$. This average value is close to those found by Bricaud et al. [1998] in Case 1 waters, and Roesler et al. [1989], Nelson and Guarda [1995], and Bowers et al. [1996] at regional scale in Case 2 waters. This is somewhat surprising because we explored a large diversity in particle composition including highly organic samples in the Baltic Sea and highly mineral-dominated samples in the North Sea and some stations of the Mediterranean Sea and English Channel. Although the $S_{\mathrm{NAP}}$ average values for the different regions were within the narrow range $0.0116-0.0130 \mathrm{~nm}^{-1}$ with the lowest values in the North Sea and the highest values in the Baltic Sea, significant differences were found (ANOVA, $p<0.0001$ ). Accordingly, two groups of regions can be identified (see Table 4). The low $S_{\text {NAP }}$ group which averaged $0.0117 \mathrm{~nm}^{-1}$ (coefficient of variation $7.9 \%$ ) included the English Channel and the North Sea, and the high $S_{\mathrm{NAP}}$ group which averaged $0.0128 \mathrm{~nm}^{-1}$ (coefficient of variation $10.0 \%$ ) included all other regions. The difference between these two groups is too small for a significant hypothesis to be made regarding its origin. It is interesting to note, however, that the average value of the low $S_{\mathrm{NAP}}$ group approaches $0.011 \mathrm{~nm}^{-1}$, which is an average found for mineral particles by Bowers et al. [1996]. Also, in the high $S_{\mathrm{NAP}}$ group, the Baltic Sea is known for its high organic matter content [Voipo, 1981; Højerslev, 1988] and we suspect that the particulate assemb- 

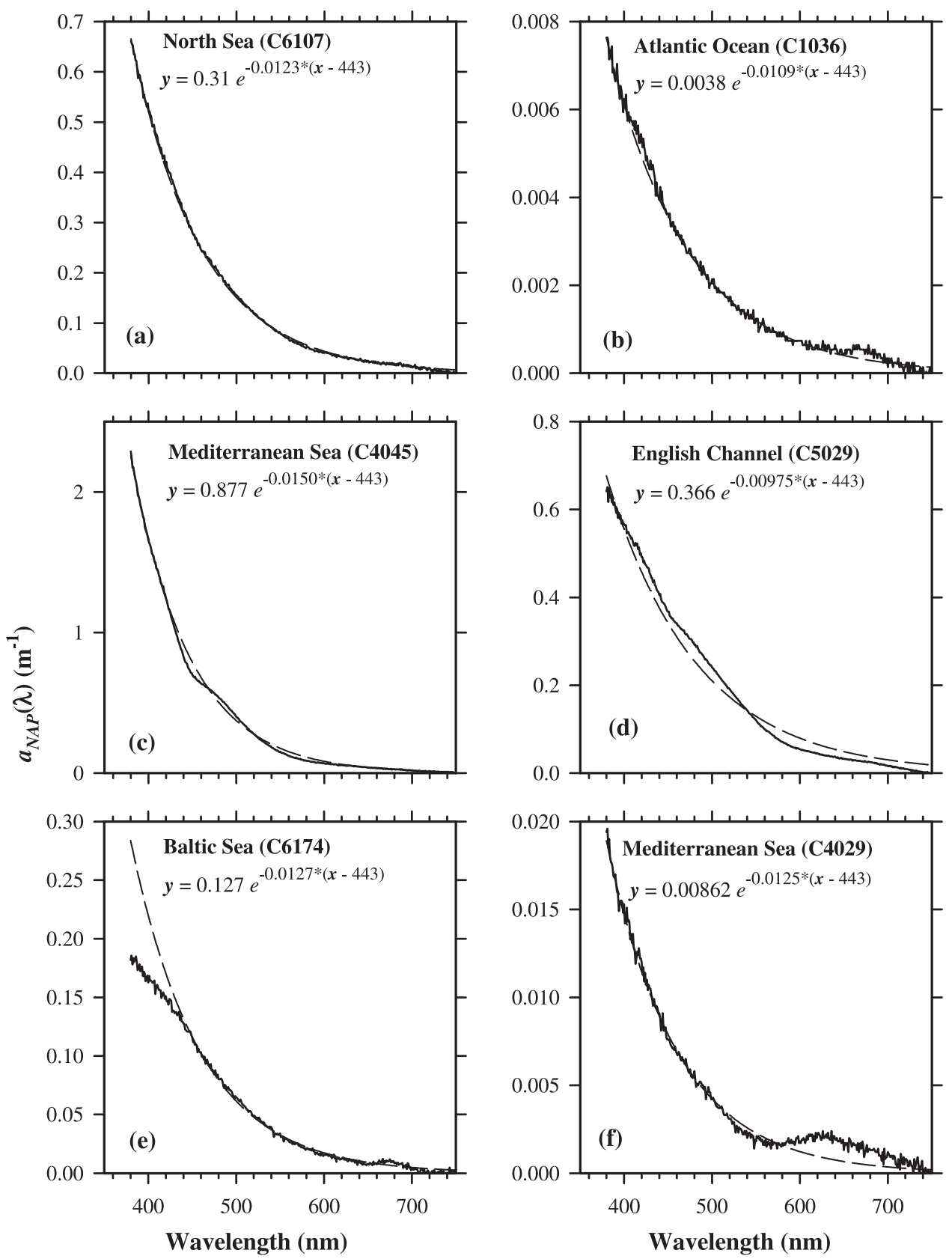

Figure 13. Six examples (a-f) of nonalgal particle absorption spectrum (solid lines) and the corresponding exponential fit (dashed lines and equations) from different regions. In each panel the station number is given in parenthesis.

Table 4. Global and Site-by-Site Statistics on the Spectral Slope of the $a_{\mathrm{NAP}}(\lambda)$ Spectrum $S_{\mathrm{NAP}}\left(\mathrm{nm}^{-1}\right)^{\mathrm{a}}$

\begin{tabular}{|c|c|c|c|c|c|c|c|c|}
\hline ID & Area & $N$ & $\begin{array}{l}\text { Minimum } \\
\text { Value }\end{array}$ & $\begin{array}{l}\text { Maximum } \\
\text { Value }\end{array}$ & $\begin{array}{l}\bar{S}_{\mathrm{NAP}}, \\
\text { Average }\end{array}$ & $\begin{array}{c}\sigma_{S_{\text {NAP }}}, \text { Standard } \\
\text { Deviation }\end{array}$ & $\begin{array}{c}\text { Variation } \\
\text { Coefficient, \% }\end{array}$ & $\begin{array}{c}\text { Different From } \\
\text { Areas, ID } \\
\end{array}$ \\
\hline $\mathrm{a}$ & Adriatic & 39 & 0.0114 & 0.0168 & 0.0128 & 0.0011 & 8.5 & $\mathrm{~d}, \mathrm{f}$ \\
\hline $\mathrm{b}$ & Atlantic & 33 & 0.0089 & 0.0161 & 0.0124 & 0.0015 & 12.0 & $\mathrm{~d}, \mathrm{f}$ \\
\hline $\mathrm{c}$ & Baltic & 54 & 0.0114 & 0.0147 & 0.0130 & 0.0007 & 5.5 & $\mathrm{~d}, \mathrm{f}$ \\
\hline $\mathrm{d}$ & Channel & 82 & 0.0093 & 0.0155 & 0.0117 & 0.0011 & 9.6 & $\mathrm{a}, \mathrm{b}, \mathrm{c}, \mathrm{e}$ \\
\hline $\mathrm{e}$ & Mediterranean & 52 & 0.0104 & 0.0178 & 0.0129 & 0.0016 & 12.8 & $\mathrm{~d}, \mathrm{f}$ \\
\hline$f$ & North Sea & 88 & 0.0096 & 0.0134 & 0.0116 & 0.0007 & 5.9 & $\mathrm{a}, \mathrm{b}, \mathrm{c}, \mathrm{e}$ \\
\hline
\end{tabular}

aAverages were compared using a Fisher PLSD test. They were considered as significantly different when $p<0.01$. The column "different from areas (ID)" shows the regions identified through ID, which are significantly different from a given region listed in the column "area." Normality of distributions has been verified successfully using a Komolgorov-Smirnov test. 

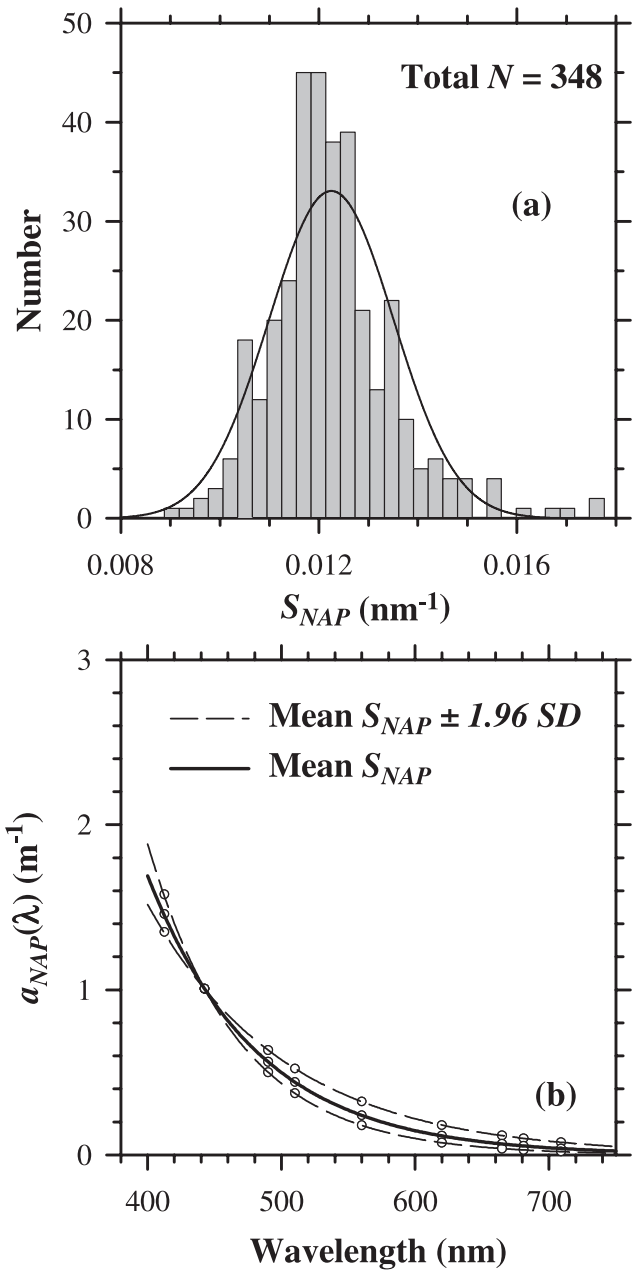

Figure 14. (a) Frequency distribution of the exponential slope, $S_{\mathrm{NAP}}$, of the NAP absorption spectrum. The Gaussian curve is also displayed to illustrate the normal distribution that corresponds to the average value of $S_{\mathrm{NAP}}(0.0123$ $\left.\mathrm{nm}^{-1}\right)$ and the standard deviation $\left(0.0013 \mathrm{~nm}^{-1}\right)$. The integrals of the observed and calculated distributions are equal. (b) The $a_{\mathrm{NAP}}(\lambda)$ spectra calculated from equation (4) with $a_{\mathrm{NAP}}\left(\lambda_{r}\right)=1, \lambda_{r}=443 \mathrm{~nm}$, and $S_{\mathrm{NAP}}=0.0123 \mathrm{~nm}^{-1}$ (solid line; the overall average found in the present study). Spectra are also shown for $S_{\mathrm{NAP}}=0.0123 \pm 1.96 \mathrm{SD} \mathrm{nm}^{-1}$, where SD $=0.0013 \mathrm{~nm}^{-1}$ (dashed lines; see Table 4). $a_{\mathrm{NAP}}(\lambda)$ at nine wavelengths representing spectral channels of the MERIS sensor (launched by the European Space Agency on the Envisat platform on 1 March 2002) are indicated as open circles.

lages in the Atlantic Ocean and the Adriatic Sea are also predominantly organic. The observed variation in $S_{\mathrm{NAP}}$ may thus be related to the proportion of mineral and organic matter.

[40] Figure 15 illustrates the relationship between $a_{\text {NAP }}(443)$ and SPM concentration. When applying a linear regression with a null intercept (see also the caption of Figure 15), we obtain a slope close to but slightly higher than the one obtained by Bowers et al. [1996] for combusted particles. The overall average $a_{\mathrm{NAP}}(443): \mathrm{SPM}$ ratio was $0.041 \mathrm{~m}^{2} \mathrm{~g}^{-1}$ with a $56 \%$ coefficient of variation.
Table 5 presents $a_{\mathrm{NAP}}(443): \mathrm{SPM}$ averages separately for the different regions. The Baltic Sea average $\left(0.067 \mathrm{~m}^{2} \mathrm{~g}^{-1}\right)$ is nearly twice as high as that in other regions (on average $0.035 \mathrm{~m}^{2} \mathrm{~g}^{-1}$ ). Also, the Atlantic Ocean average is significantly higher than the English Channel, Mediterranean Sea, and North Sea values. Given the conditions in the Baltic, these results suggest that organic particles may have a higher $a_{\mathrm{NAP}}(443)$ :SPM ratio than inorganic particles. The agreement between the Bowers et al. regression line and our most inorganic samples (the North Sea and English Channel) also supports this interpretation (see Figure 15). We note that the Bowers et al. analysis was fully consistent in a sense that it compared combusted particle absorption with combusted particle dry weight. Our analysis, on the other hand, is to some extent ambiguous because we compare absorption by NAP only (excluding phytoplankton) with the dry weight of all particles (including phytoplankton). As a result, our estimates of $a_{\mathrm{NAP}}(443)$ :SPM are probably lower than the actual $a_{\mathrm{NAP}}(443)$-to-NAP dry weight ratio. This effect is expected to be most important in Case 1 waters where phytoplankton represent a significant fraction of the dry weight.

[41] In summary, although we observed some variability in the $a_{\mathrm{NAP}}(\lambda)$ spectrum, the overall spectral shape is rather conservative for most coastal systems that we investigated. The spectral slope $S_{\mathrm{NAP}}$ varies within a narrow range. This limited variability is remarkable given that $a_{\mathrm{NAP}}(\lambda)$ varied

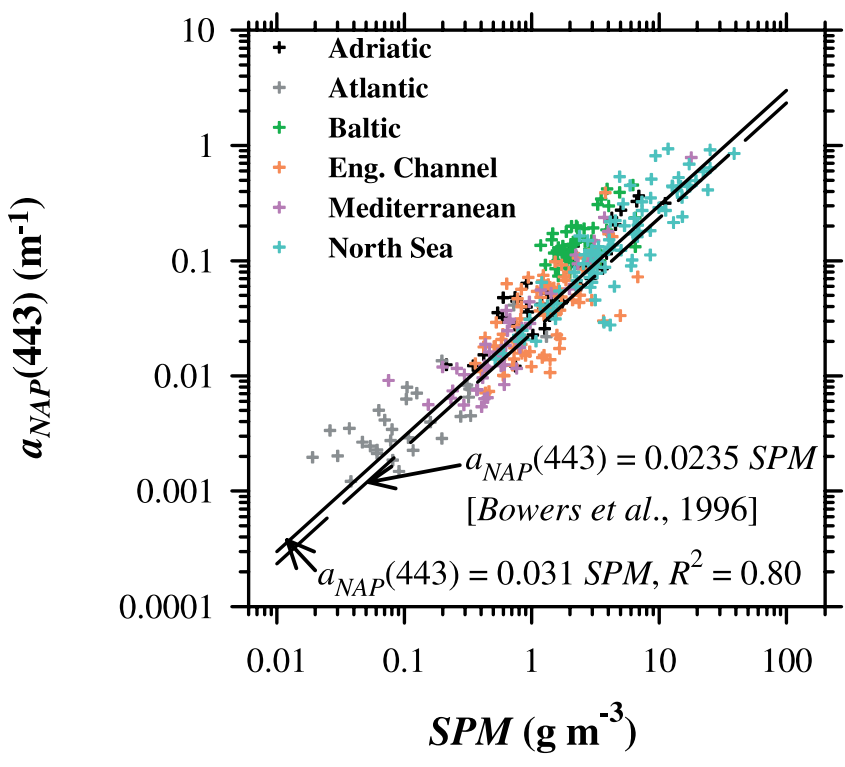

Figure 15. Scatterplot of $a_{\mathrm{NAP}}(443)$ as a function of SPM. A linear regression with null intercept is shown (solid line) together with the one derived by Bowers et al. [1996] (dashed line). The regression of Bowers et al. was obtained with the absorption coefficient at $440 \mathrm{~nm}$ uncorrected for the path length amplification factor (the so-called $\beta$ factor). For the sake of comparison, we first transformed this original result (their equation (4)) by dividing the slope of the regression by 4 , which corresponds to the $\beta$ factor derived in their study. Then we applied the average $S_{\mathrm{NAP}}$ value of Bowers et al. to calculate the slope at $443 \mathrm{~nm}$ (rather than $440 \mathrm{~nm}$ ); the final result of this calculation is the dashed line. 
Table 5. Global and Site-by-Site Statistics on the $a_{\mathrm{NAP}}(443)$ :SPM Ratio $^{\mathrm{a}}$

\begin{tabular}{|c|c|c|c|c|c|c|}
\hline ID & Area & $N$ & Average & SD & $\begin{array}{c}\text { Variation } \\
\text { Coefficient, } \\
\% \\
\end{array}$ & $\begin{array}{l}\text { Different } \\
\text { From } \\
\text { Areas, ID }\end{array}$ \\
\hline $\mathrm{a}$ & Adriatic & 38 & 0.041 & 0.017 & 39 & $\mathrm{c}$ \\
\hline b & Atlantic & 30 & 0.044 & 0.030 & 68 & $\mathrm{c}, \mathrm{d}, \mathrm{e}, \mathrm{f}$ \\
\hline $\mathrm{c}$ & Baltic & 52 & 0.067 & 0.022 & 33 & $a, b, d, e, f$ \\
\hline d & Channel & 77 & 0.035 & 0.018 & 51 & $\mathrm{~b}, \mathrm{c}$ \\
\hline $\mathrm{e}$ & Mediterranean & 48 & 0.036 & 0.019 & 53 & $\mathrm{~b}, \mathrm{c}$ \\
\hline f & North Sea & 83 & 0.033 & 0.016 & 48 & $\mathrm{~b}, \mathrm{c}$ \\
\hline .. & all & 328 & 0.041 & 0.023 & 56 & $\ldots$ \\
\hline$\ldots$ & all except Baltic & 288 & 0.036 & 0.025 & 69 & $\ldots$ \\
\hline
\end{tabular}

${ }^{a}$ Averages were compared using a Fisher PLSD test. They were considered as significantly different when $p<0.05$. The column "different from areas (ID)" shows the regions identified through ID, which are significantly different from a given region listed in the column "area." Normality of distributions has been verified successfully using a Komolgorov-Smirnov test.

over nearly three orders of magnitude at any wavelength in our data set. The $a_{\mathrm{NAP}}(\lambda)$ spectra in the Baltic Sea were peculiar with regard to the two issues: (1) the spectral curves showed a rather unusual drop relative to the exponential fit at $\lambda$ shorter than $440 \mathrm{~nm}$ (Figure 13) and (2) the $a_{\mathrm{NAP}}(443): \mathrm{SPM}$ ratio was significantly higher than in other regions (Figure 15 and Table 5).

[42] Our results show that, on average, NAP absorption could be expressed as:

$$
a_{\mathrm{NAP}}(\lambda)=a_{\mathrm{NAP}}(443)\left[0.75 \mathrm{e}^{(-0.0123(\lambda-443))}\right] .
$$

Figure $14 \mathrm{~b}$ illustrates this equation and the range that comprises $95 \%$ of COAST $\ell$ OOC samples, that is the average $S_{\mathrm{NAP}}$ value \pm 1.96 times the standard deviation. At $412 \mathrm{~nm}$ where NAP absorption is significant, the ratio $a_{\mathrm{NAP}}(412): a_{\mathrm{NAP}}(443)$ is, on average, 1.46 , and in extreme cases 1.35 or 1.58 . At $560 \mathrm{~nm}$ where NAP absorption is low, the ratio $a_{\mathrm{NAP}}(560): a_{\mathrm{NAP}}(443)$ is, on average, 0.24 , and in extreme cases 0.18 or 0.32 .

\subsection{Absorption Budget}

[43] Twenty years ago, Prieur and Sathyendranath [1981] derived an absorption budget from a statistical analysis of $K_{d}$ and reflectance, in which the absorption coefficient was partitioned into the three components associated with CDOM, phytoplankton, and NAP. They introduced the concept of a triangular classification of natural waters based on this budget. From the results at $440 \mathrm{~nm}$, Prieur and Sathyendranath found that open ocean samples were dominated by phytoplankton absorption, and therefore were systematically located close to the phytoplankton apex of the triangular diagram. Their coastal samples were scattered over the central part of the diagram. IOCCG [2000] extended this classification concept by proposing that typical open ocean (Case 1) waters samples should be systematically found close to the phytoplankton apex, while those from coastal (Case 2) waters could be found anywhere else in the diagram because relative proportions of the three absorption components are expected to vary widely in these waters.

[44] Figure 16 illustrates the absorption budget derived from our data as triangular diagrams at ten different wave- lengths. At $443 \mathrm{~nm}$ where the three absorption components absorb significantly, our data show that relative contributions to absorption are comprised within a restricted range. For $73 \%$ of our samples the relative contributions of CDOM, phytoplankton, and NAP lie simultaneously between 0.4 and $0.8,0.2$ and 0.6 , and 0.1 and 0.4 , respectively. In the triangular diagram at $443-560 \mathrm{~nm}$, most samples are located within the central zone. This pattern results from the fact that the three absorption components covary to some extent. Significant differences (ANOVA, $p<0.0001$ ) are nevertheless found between the examined oceanic areas in terms of the relative contribution of each absorption component, as illustrated in the triangular diagram by distinct data point aggregates and as detailed in Table 6. As suggested by the analysis of TChl, $a_{\mathrm{CDOM}}(443)$, and SPM in section 3.1, the absorption budget at $443 \mathrm{~nm}$ indicates that phytoplankton absorption was, on average, dominant in the Adriatic Sea and was relatively low in the North Sea. The CDOM absorption was dominant in the Baltic Sea as expected, and more surprisingly, also in the open Atlantic Ocean. Our Mediterranean Sea samples occupy a large part of the triangular diagram at $443 \mathrm{~nm}$ with the highest contribution by NAP for some samples. The lowest contributions by NAP were generally found in the Atlantic Ocean. These results show that the triangular representation of data provides a means to optically characterize natural waters. However, the partitioning of the absorption coefficient into CDOM, phytoplankton, and NAP contributions varies within a restricted range because of covariability. Also, the triangular diagrams of our data show no clear separation of Case 1 and Case 2 waters. This is because our open ocean samples exhibited relatively high contributions by CDOM, within a range consistent with previous observations [e.g., Nelson et al., 1998].

[45] Spectral changes in the triangular diagrams reveal interesting, although expected, patterns. The CDOM contribution to absorption was generally dominant in the near ultraviolet and nearly null in the near infrared. The NAP contribution was in general highest at $560 \mathrm{~nm}$. Except for some Mediterranean samples, phytoplankton strongly dominated absorption at $665 \mathrm{~nm}$. Thus one can identify specific parts of the visible spectrum where any one of the three components dominates absorption $a(\lambda)-a_{w}(\lambda)$.

\section{Conclusions}

[46] In summary, we found that the slope of the exponential function describing CDOM absorption shows relatively little variability for the entire data set which includes diverse coastal waters around Europe. If all coastal regions examined are considered together, the phytoplankton absorption as a function of TChl shows a similar trend to that previously observed in open ocean waters by Bricaud et al. [1995]. However, we caution against indiscriminate use of this general relationship for any specific coastal region because of significant variability and differences among the regions observed in our data set. In particular, the high phaeopigment concentrations in coastal waters may lead to larger and unpredictable variations in $a_{\phi}(\lambda)$, in contrast to Case 1 waters where these pigments play a minor role. Moreover, high pheopigment concentrations could make the biomass of living phytoplankton more difficult to estimate. 

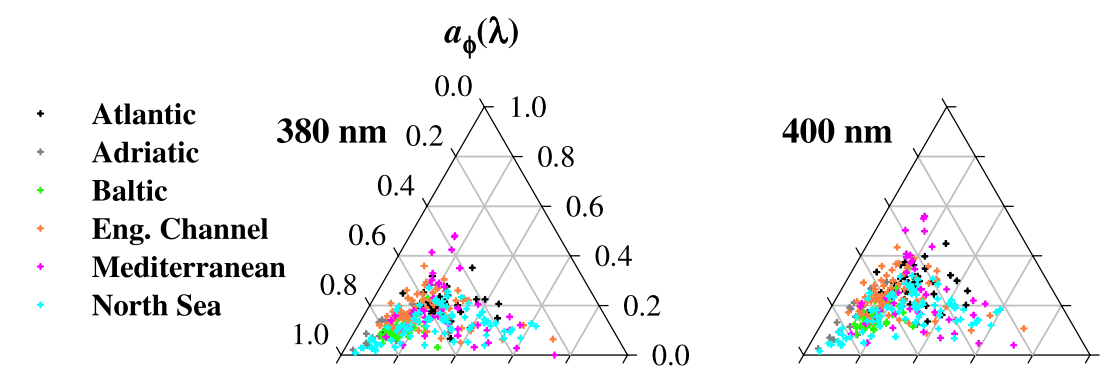

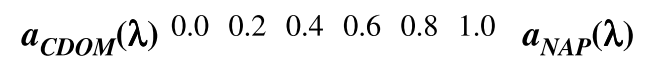
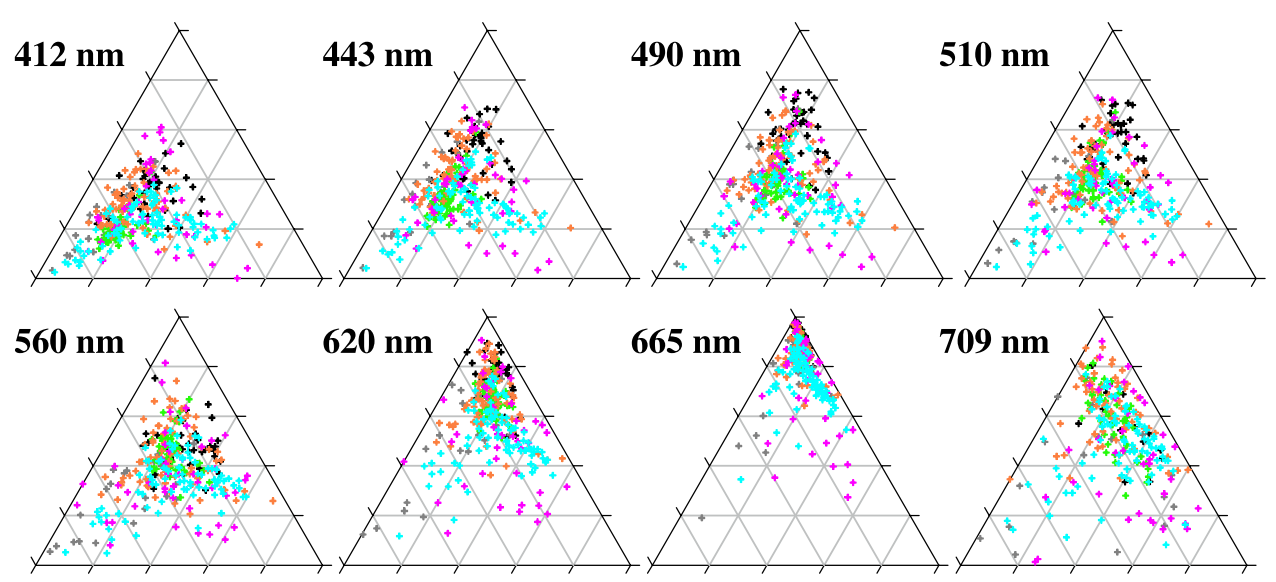

Figure 16. Ternary plots illustrating the relative contribution of CDOM, phytoplankton, and NAP to absorption, for all samples in this study and different wavelengths. The relative proportion (within a $0-1$ scale) of a given absorption component $x$ for a given sample was calculated as $x(x+y+z)^{-1}$ where y and $\mathrm{z}$ are the two remaining components. The higher the relative contribution of a given component for a given sample is, the closer to the corresponding apex (see component labels) the data point is. The relative contribution of a given absorption component for a given sample can be read on the corresponding axis, where the component label is positioned at the maximum of the scale for that component.

Finally, we observed weak variations in the exponential slope of NAP absorption. We found, however, that in some waters distinct spectral features associated with diversity in the nature of organic and inorganic particulate matter can be superimposed on the general exponential shape of NAP spectra.

[47] Our results allow us to be optimistic about applications where $a_{\phi}(\lambda)$ has to be retrieved from the deconvolution of the $a(\lambda)-a_{w}(\lambda)$ spectrum [e.g., Schofield et al., 1999] because the shape of the $a_{\mathrm{CDOM}}(\lambda)$ and $a_{\mathrm{NAP}}(\lambda)$ spectra showed small variations. With regard to ocean color remote sensing, our results support the idea that algorithms may have to be developed at regional scales to perform well in coastal waters, and it may be necessary to continuously acquire sea-truth data for validation purposes.

\section{Notation}

$\lambda$ wavelength in a vacuum (nm).

$a$ total absorption coefficient $\left(\mathrm{m}^{-1}\right)$.

$a_{w}$ pure water absorption coefficient $\left(\mathrm{m}^{-1}\right)$.

$a_{\mathrm{CDOM}}$ CDOM absorption coefficient $\left(\mathrm{m}^{-1}\right)$.

Table 6. Relative Contributions (Scaled Between 0 and 1) of Phytoplankton, CDOM, and NAP Absorption to $a(443)-a_{w}(443)^{\mathrm{a}}$

\begin{tabular}{|c|c|c|c|c|c|c|c|c|}
\hline \multirow[b]{2}{*}{ ID } & \multirow[b]{2}{*}{ Area } & \multirow[b]{2}{*}{$N$} & \multicolumn{2}{|c|}{$a_{\phi}(443):\left(a(443)-a_{w}(443)\right)$} & \multicolumn{2}{|c|}{$a_{\mathrm{CDOM}}(443):\left(a(443)-a_{w}(443)\right)$} & \multicolumn{2}{|c|}{$a_{\mathrm{NAP}}(443):\left(a(443)-a_{w}(443)\right)$} \\
\hline & & & $\begin{array}{c}\text { Average } \pm \\
\text { Standard Deviation }\end{array}$ & $\begin{array}{c}\text { Different From } \\
\text { Areas, ID }\end{array}$ & $\begin{array}{c}\text { Average } \pm \\
\text { Standard Deviation }\end{array}$ & $\begin{array}{c}\text { Different From } \\
\text { Areas, ID }\end{array}$ & $\begin{array}{c}\text { Average } \pm \\
\text { Standard Deviation }\end{array}$ & $\begin{array}{c}\text { Different From } \\
\text { Areas, ID }\end{array}$ \\
\hline $\mathrm{a}$ & Adriatic & 39 & $0.52 \pm 0.10$ & $\mathrm{~b}, \mathrm{c}, \mathrm{d}, \mathrm{e}, \mathrm{f}$ & $0.28 \pm 0.08$ & $\mathrm{~b}, \mathrm{c}, \mathrm{d}, \mathrm{e}, \mathrm{f}$ & $0.20 \pm 0.08$ & $\mathrm{~b}, \mathrm{e}, \mathrm{f}$ \\
\hline $\mathrm{b}$ & Atlantic & 19 & $0.33 \pm 0.14$ & $\mathrm{a}, \mathrm{d}$ & $0.56 \pm 0.17$ & $\mathrm{a}, \mathrm{c}, \mathrm{d}, \mathrm{e}, \mathrm{f}$ & $0.11 \pm 0.06$ & $\mathrm{a}, \mathrm{c}, \mathrm{d}, \mathrm{e}, \mathrm{f}$ \\
\hline $\mathrm{c}$ & Baltic & 54 & $0.32 \pm 0.07$ & $a, d$ & $0.48 \pm 0.07$ & $\mathrm{a}, \mathrm{b}, \mathrm{d}, \mathrm{e}$ & $0.20 \pm 0.05$ & $\mathrm{~b}, \mathrm{e}, \mathrm{f}$ \\
\hline d & Channel & 75 & $0.42 \pm 0.10$ & $a, b, c, e, f$ & $0.39 \pm 0.10$ & $a, b, c, f$ & $0.19 \pm 0.12$ & $\mathrm{~b}, \mathrm{e}, \mathrm{f}$ \\
\hline e & Med. & 45 & $0.36 \pm 0.17$ & $\mathrm{a}, \mathrm{d}, \mathrm{f}$ & $0.38 \pm 0.13$ & $\mathrm{a}, \mathrm{b}, \mathrm{c}, \mathrm{f}$ & $0.27 \pm 0.16$ & $\mathrm{a}, \mathrm{b}, \mathrm{c}, \mathrm{d}$ \\
\hline $\mathrm{f}$ & North Sea & 85 & $0.28 \pm 0.10$ & $\mathrm{a}, \mathrm{d}, \mathrm{e}$ & $0.44 \pm 0.17$ & $\mathrm{a}, \mathrm{b}, \mathrm{d}, \mathrm{e}$ & $0.28 \pm 0.15$ & $a, b, c, d$ \\
\hline$\ldots$ & all & 317 & $0.36 \pm 0.14$ & $\ldots$ & $0.41 \pm 0.14$ & $\ldots$ & $0.22 \pm 0.13$ & $\ldots$ \\
\hline
\end{tabular}

a Averages were compared using a Fisher PLSD test. They were considered as significantly different when $p<0.01$. The column "different from areas (ID)" shows the regions identified through ID, which are significantly different from a given region listed in the column "area." Normality of distributions has been verified successfully using a Komolgorov-Smirnov test. 
$\hat{a}_{\mathrm{CDOM}}\left(\lambda_{r}\right) \mathrm{CDOM}$ absorption coefficient at reference wavelength estimated by fitting equation (2) to $a_{\mathrm{CDOM}}(\lambda)$ data $\left(\mathrm{m}^{-1}\right)$.

$a_{\phi}$ phytoplankton absorption coefficient $\left(\mathrm{m}^{-1}\right)$.

$\hat{a}_{\phi}$ phytoplankton absorption coefficient estimated as a function of TChl using the statistics of Bricaud et al. [1995] $\left(\mathrm{m}^{-1}\right)$.

$\hat{a}_{\infty}^{*}$ phytoplankton chlorophyll-specific absorption coefficient estimated as a function of TChl using the statistics of Bricaud et al. [1995] $\left(\mathrm{m}^{-1}\right)$.

$a_{\mathrm{NAP}}$ nonalgal particle absorption coefficient $\left(\mathrm{m}^{-1}\right)$.

$\hat{a}_{\mathrm{NAP}}\left(\lambda_{r}\right)$ nonalgal particle absorption coefficient at reference wavelength estimated by fitting equation (4) to $a_{\mathrm{NAP}}(\lambda)$ data $\left(\mathrm{m}^{-1}\right)$.

$a_{p}$ particle absorption coefficient $\left(\mathrm{m}^{-1}\right)$.

Chl $a$ total chlorophyll $a$ concentration, including monovinyl- and divinyl-chlorophyll $a$, chlorophyll $a$ isomer and epimer, and chlorophyllids $a\left(\mathrm{mg} \mathrm{m}^{-3}\right)$.

TChl sum of Chl $a$ and phaeopigments $\left(\mathrm{mg} \mathrm{m}^{-3}\right)$.

SPM particle dry weight $\left(\mathrm{g} \mathrm{m}^{-3}\right)$.

$S_{\mathrm{CDOM}}$ spectral slope of the exponential fit applied to the CDOM absorption spectrum $\left(\mathrm{nm}^{-1}\right)$ (equation (2)).

$S_{\mathrm{NAP}}$ spectral slope of the exponential fit applied to the nonalgal particle absorption spectrum $\left(\mathrm{nm}^{-1}\right)$ (equation (4)).

NPC concentration of nonphotosynthetic pigments (see definition in section 2.4) $\left(\mathrm{mg} \mathrm{m}^{-3}\right)$.

[48] Acknowledgments. This study was funded by the European Commission (Environment and Climate Program, contract ENV4-CT960310) and the European Space Agency. Ship time was provided by the Reedereigemeinschaft Forschungsschiffahrt and Institut National des Sciences de l'Univers. Partial support was also provided by the ONR Environmental Optics Program (grant N00014-98-1-0003). We are grateful to the crews of R.V. Victor Hensen, R.V. Poseidon, and R.V. Tethys2, and to Commerc'Air SA staff for their support during field operations. We also thank F. Fell, V. Fournier-Sicre, N. Hoepffner, F. Lahet, K. Oubelkheir, and E. Roussier for their help in the field. We are grateful to M. Pinkerton, M. Wernand, and $\mathrm{H}$. Barth for their assistance in the organization of field operations. Many thanks to B. Gentili for his efficient contribution to computations. Comments by A. Morel are much appreciated.

\section{References}

Allali, K., A. Bricaud, and H. Claustre, Spatial variations in the chlorophyll-specific absorption coefficients of phytoplankton and photosynthetically active pigments in the equatorial Pacific, J. Geophys. Res., 102(C6), 12,413-12,423, 1997.

Babin, M., and D. Stramski, Light absorption by aquatic particles in the near-infrared spectral region, Limnol. Oceanogr., 47(3), 911-915, 2002.

Babin, M., J.-C. Therriault, L. Legendre, and A. Condal, Variations in the specific absorption coefficient for natural phytoplankton assemblages: Impact on estimates of primary production, Limnol. Oceanogr., 38, $154-177,1993$

Babin, M., A. Morel, H. Claustre, A. Bricaud, Z. S. Kolber, and P. G. Falkowski, Nitrogen- and irradiance-dependent variations of the maximum yield of carbon fixation in eutrophic, mesotrophic and oligotrophic marine systems, Deep Sea Res., 43, 1241-1272, 1996.

Barnard, A. H., W. S. Pegau, and J. R. V. Zaneveld, Global relationships of the inherent optical properties of the oceans, J. Geophys. Res., 103(C11), 24,955-24,968, 1998.

Blough, N. V., O. C. Zafiriou, and J. Bonilla, Optical absorption spectra of waters from the Orinoco River outflow: Terrestrial input of colored organic matter to the Carribean, J. Geophys. Res., 98(C2), 2271-2278, 1993.

Bowers, D. G., G. E. L. Harker, and B. Stephan, Absorption spectra of inorganic particles in the Irish Sea and their relevance to remote sensing of chlorophyll, Int. J. Remote Sens., 17(12), 2449-2460, 1996.
Bricaud, A., and A. Morel, Light attenuation and scattering by phytoplanktonic cells: A theoretical modeling, Appl. Opt., 25(4), 571-580, 1986.

Bricaud, A., and D. Stramski, Spectral absorption coefficients of living phytoplankton and nonalgal biogenous matter: A comparison between Peru upwelling area and the Sargasso Sea, Limnol. Oceanogr., 35, $562-582,1990$

Bricaud, A., A. Morel, and L. Prieur, Absorption by dissolved organic matter of the sea (yellow substance) in the UV and visible domains, Limnol. Oceanogr., 26(1), 43-53, 1981.

Bricaud, A., M. Babin, A. Morel, and H. Claustre, Variability in the chlorohypll-specific absorption coefficients of natural phytoplankton: Analysis and parameterization, J. Geophys. Res., 100(C7), 13,321-13,332, 1995.

Bricaud, A., A. Morel, M. Babin, K. Allali, and H. Claustre, Variations of light absorption by suspended particles with the chlorophyll a concentration in oceanic (case 1) waters: Analysis and implications for bio-optical models, J. Geophys. Res., 103, 31,033-31,044, 1998.

Bricaud, A., H. Claustre, G. Obolensky, and M. Babin, Light absorption by suspended particles and phytoplankton in Case 2 waters, in Ocean Optics $X V$ [CD ROM], edited by S. G. Acklesson and J. Marra, Off. of Naval Res., Washington, D. C., Monaco, 2000.

Bukata, R. P., J. H. Jerome, J. E. Bruton, S. C. Jain, and H. H. Zwick, Optical water quality model of Lake Ontario, I, Determination of the optical cross sections of organic and inorganic particulates in Lake Ontario, Appl. Opt., 20(9), 1696-1703, 1981.

Bukata, R. P., J. H. Jerome, K. Y. Kondratyev, and D. V. Pozdnyakov, Optical Properties and Remote Sensing of Inland and Coastal Waters, 362 pp., C.R.C. Press, Boca Raton, Fla., 1995.

Carder, K. L., R. G. Steward, G. R. Harvey, and P. B. Ortner, Marine humic and fulvic acids: Their effects on remote sensing of ocean chlorophyll, Limnol. Oceanogr., 34(1), 68-81, 1989.

Carder, K. L., S. K. Hawes, K. A. Baker, R. C. Smith, R. G. Steward, and B. G. Mitchell, Reflectance model for quantifying chlorohyll $a$ in the presence of productivity degradation products, J. Geophys. Res., 96(C11), 20,599-20,611, 1991 .

Claustre, H., Phytoplankton pigment signatures of the trophic status in various oceanic regimes, Limnol. Oceanogr., 39(5), 1207-1211, 1994.

Claustre, H., F. Fell, K. Oubelkheir, L. Prieur, A. Sciandra, B. Gentili, and M. Babin, Continuous monitoring of surface optical properties across a geostrophic front: Biogeochemical inferences, Limnol. Oceanogr., 45(2), 309-321, 2000

Cleveland, J. S., Regional models for phytoplankton absorption as a function of chlorophyll $a$ concentration, J. Geophys. Res., 100(C7), 13,333$13,344,1995$

Cleveland, J. S., and M. J. Perry, A model for partitioning particulate absorption into phytoplankton and detrital components, Deep Sea Res., Part I, 41(1), 197-221, 1994

Duarte, C. M., S. Agustí, M. P. Satta, and D. Vaqué, Partitioning particulate light absorption: A budget for a Mediterranean bay, Limnol. Oceanogr., 43(2), 236-244, 1998.

Ferrari, G. M., and M. D. Dowell, CDOM absorption characteristics with relation to fluorescence and salinity in coastal areas of the southern Baltic Sea, Estuarine Coastal Shelf Sci., 47, 91-105, 1998.

Ferrari, G. M., and S. Tassan, A method using chemical oxidation to remove light absorption by phytoplankton pigments, J. Phycol., 35, 1090-1098, 1999.

Gallegos, C. L., D. L. Correll, and J. W. Pierce, Modeling spectral diffuse attenuation, absorption, and scattering coefficients in a turbid estuary, Limnol. Oceanogr., 35(7), 1486-1502, 1990.

Gallie, E. A., and P. A. Murtha, Specific absorption and backscattering spectra for suspended minerals and chlorophyll $a$ in Chilko Lake, British Columbia, Remote Sens. Environ., 39, 103-118, 1992.

Gordon, H. R., O. B. Brown, O. B. Evans, J. W. Brown, R. C. Smith, K. A. Baker, and D. K. Clark, A semianalytical radiance model of ocean color, J. Geophys. Res., 93, 8670-8684, 1988.

Gross, L., S. Thiria, R. Frouin, and B. G. Mitchell, Artificial neural networks for modeling the transfer function between marine reflectance and phytoplankton pigment concentration, J. Geophys. Res., 105(C2), 3483$3495,2000$.

Hoepffner, N., and S. Sathyendranath, Effect of pigment composition on absorption properties of phytoplankton, Mar. Ecol. Prog. Ser., 73, 11-23, 1991.

Højerslev, N. K., Natural Occurrences and Optical Effects of Gelbstoff, 30 pp., Dep. of Phys. Oceanogr., Geophys. Inst., Copenhagen Univ., Copenhagen, Denmark, 1988

IOCCG, Remote sensing of ocean colour in coastal, and optically-complex, waters, in Reports of the International Ocean-Colour Coordinating Group, no. 3, edited by S. Sathyendranath, pp. 140, Dartmouth, 2000.

Johnsen, G., O. Samset, L. Granskog, and E. Sakshaug, In vivo absorption characteristics in 10 classes of bloom-forming phytoplankton: Taxonomic 
characteristics and responses to photoadaptation by means of discriminant and HPLC analysis, Mar. Ecol. Prog. Ser., 105, 149-157, 1994.

Kalle, K., Zum problem der meereswasserfarbe, Ann. Hydrol. Mar. Mitt., $66,1-13,1938$.

Kirk, J. T. O., Spectral absorption properties of natural waters: Contribution of the soluble and particulate fractions to light absorption in some inland waters of south-eastern Australia, Aust. J. Mar. Freshwater Res., 31, 287-296, 1980 .

Kirk, J. T. O., Effects of suspensoids (turbidity) on penetration of solar radiation in aquatic ecosystems, Hydrobiologia, 125, 195-208, 1985.

Kirk, J. T. O., Light and Photosynthesis in Aquatic Ecosystems, 509 pp., Cambridge Univ. Press, New york, 1994.

Kirk, J. T. O., and R. L. Oliver, Optical closure in an ultraturbid lake, J. Geophys. Res., 100(C7), 13,221-13,225, 1995.

Kirk, J. T. O., and P. A. Tyler, The spectral absorption and scattering properties of dissolved and particulate components in relation to the underwater light field of some tropical Australian freshwaters, Freshwater Biol., 16, 573-583, 1986.

Kowalczuk, P., Seasonal variability of yellow substance absorption in the surface layer of the Baltic Sea, J. Geophys. Res., 104(C12), 30,04730,058, 1999.

Kratzer, S., D. Bowers, and P. B. Tett, Seasonal changes in colour ratios and optically active constituents in the optical Case-2 waters of the Menai Strait, North Wales, Int. J. Remote Sens., 21(11), 2225-2246, 2000.

Lewis, M. R., J. J. Cullen, and T. Platt, Relationships between vertical mixing and photoadaptation of phytoplankton: Similarity criteria, Mar. Ecol. Prog. Ser., 15, 141-149, 1984.

Lorenzen, C. J., and J. N. Downs, The specific absorption coefficients of chlorophyllide $a$ and pheophorbide $a$ in $90 \%$ acetone, and comments on the fluorometric determination of chlorophyll and pheopigments, Limnol. Oceanogr., 31(2), 449-452, 1986.

Mitchell, B. G., and D. A. Kiefer, Variability in pigment specific particulate fluorescence and absorption spectra in the northeastern Pacific Ocean, Limnol. Oceanogr., 35(5), 665-689, 1988.

Morel, A., Optical modeling of the upper ocean in relation to its biogenous matter content (Case I waters), J. Geophys. Res., 93(C9), 10,749-10,768, 1988.

Morel, A., and J.-F. Berthon, Surface pigments, algal biomass profiles, and potential production of the euphotic layer: Relationships reinvestigated in view of remote-sensing applications, Limnol. Oceanogr., 34(8), $1545-$ $1562,1989$.

Morel, A., and S. Maritorena, Bio-optical properties of oceanic waters: A reappraisal, J. Geophys. Res., 106, 7763-7780, 2001.

Morel, A., and L. Prieur, Analysis of variations in ocean color, Limnol. Oceanogr., 22, 709-722, 1977.

Mueller, J. L., and R. W. Austin, Ocean optics protocols for SeaWIFS validation: Revision 1, SeaWIFS technical report series, NASA Tech. Memo., 66 pp., Greenbelt, Md., 1995.

Nelson, J. R., and S. Guarda, Particulate and dissolved spectral absorption on the continental shelf of the southeastern United States, J. Geophys. Res., 100(C5), 8715-8732, 1995.

Nelson, N. B., D. A. Siegel, and A. F. Michaels, Seasonal dynamics of colored dissolved material in the Sargasso Sea, Deep Sea Res., Part I, 45(6), 931-957, 1998

Oliver, R. L., Optical properties of waters in the Murray-Darling Basin, south-eastern Australia, Aust. J. Mar. Freshwater Res., 41, 581-601, 1990.

Pegau, W. S., G. Deric, and J. R. V. Zaneveld, Absorption and attenuation of visible and near-infrared light in water: Dependence on temperature and salinity, Appl. Opt., 36(24), 6035-6046, 1997.

Prieur, L., and S. Sathyendranath, An optical classification of coastal and oceanic waters based on the specific spectral absorption curves of phytoplankton pigments, dissolved organic matter, and other particulate materials, Limnol. Oceanogr., 26(4), 671-689, 1981

Reynolds, R. A., D. Stramski, and B. G. Mitchell, A chlorophyll-dependent semianalytical reflectance model derived from field measurement of absorption and backscattering coefficients within the Southern Ocean, J. Geophys. Res., 106(C4), 7125-7138, 2001.

Roesler, C. S., and M. J. Perry, In situ phytoplankton absorption, fluorescence emission, and particulate backscattering spectra determined from reflectance, J. Geophys. Res., 100(C7), 13,279-13,294, 1995.

Roesler, C. S., M. J. Perry, and K. L. Carder, Modeling in situ phytoplankton absorption from total absorption spectra in productive inland marine waters, Limnol. Oceanogr., 34(8), 1510-1523, 1989.

Schofield, O., J. Grzymski, W. P. Bissett, G. J. Kirkpatrick, D. F. Millie, M. Moline, and C. S. Roesler, Optical monitoring and forecasting systems for harmful algal blooms: Possibility or pipe dream?, J. Phycol., 35, 1477-1496, 1999.
Siegel, D. A., and A. F. Michaels, Quantification of non-algal light attenuation in the Sargasso Sea: Implications for biogeochemistry and remote sensing, Deep Sea Res., 43(2-3), 321-345, 1996.

Sokal, R. S., and F. J. Rohlf, Biometry, 859 pp., W. H. Freeman, New York, 1981.

Sosik, H. M., and B. G. Mitchell, Light absorption by phytoplankton, photosynthetic pigments and detritus in the California Current System, Deep Sea Res., Part I, 42(10), 1717-1748, 1995.

Spitzy, A., and V. Ittekkot, Gelbstoff: An uncharacterized fraction of dissolved organic carbon, in The Influence of Yellow Substances on Remote Sensing of Sea-Water Constituent From Space, GKSS, Geesthacht, Germany, 1986.

Stramski, D., A. Bricaud, and A. Morel, Modeling the inherent optical properties of the ocean based on the detailed composition of planktonic community, Appl. Opt., 40(18), 2929-2945, 2001.

Tassan, S., and G. M. Ferrari, An alternative approach to absorption measurements of aquatic particles retained on filters, Limnol. Oceanogr., 40, 1358-1368, 1995a.

Tassan, S., and G. M. Ferrari, Proposal for the measurement of backward and total scattering by mineral particles suspended in water, Appl. Opt., $34,8345-8353,1995 \mathrm{~b}$

Tassan, S., and G. M. Ferrari, Measurement of the light absorption by aquatic particulates retained on filters: Determination of the optical pathlength amplification by the "transmittance-reflectance" method, J. Plankton Res., 20, 1699-1709, 1998.

Tassan, S., G. M. Ferrari, A. Bricaud, and M. Babin, Variability of the amplification factor of light absorption by filter-retained aquatic particles in the coastal environment, J. Plankton Res., 22(4), 659-668, 2000.

Trees, C. C., D. K. Clark, R. R. Bidigare, M. E. Ondrusek, and J. L. Mueller, Accessory pigments versus chlorophyll $a$ concentration within the euphotic zone: A ubiquitous relationship, Limnol. Oceanogr., 45(5), $1130-1143,2000$.

Van der Linde, D. W., Protocol for determination of total suspended matter in oceans and coastal zones, Tech. Note I.98.182, Joint Res. Cent., Brussels, 1998.

Vernet, M., and C. J. Lorenzen, The relative abundance of pheophytin a in temperate marine waters, Limnol. Oceanogr., 32, 352-358, 1987.

Vidussi, F., H. Claustre, J. Bustillos-Guzman, C. Caillau, and J.-C. Marty, Rapid HPLC method for determination of phytoplankton chemotaxinomic pigments: Separation of chlorophyll $a$ from divinyl-chlorophyll $a$, and zeaxanthin from lutein., J. Plankton Res., 18, 2377-2382, 1996.

Vidussi, F., H. Claustre, B. Manca, A. Luchetta, and J.-C. Marty, Phytoplankton pigment distribution in relation to the upper thermocline circulation in the eastern Mediterranean Sea during winter, J. Geophys. Res., 106, 19,939-29,956, 2001 .

Vodacek, A., N. V. Blough, M. D. DeGrandpre, E. T. Peltzer, and R. K. Nelson, Seasonal variation of CDOM and DOC in the middle Atlantic Bight: Terrestrial inputs and photooxidation, Limnol. Oceanogr., 42(4), 674-686, 1997

Voipo, A., The Baltic Sea, 416 pp., Elsevier Sci., New York, 1981.

Warnock, R. E., W. W. C. Gieskes, and S. van Laar, Regional and seasonal differences in light absorption by yellow substance in the Southern Bight of the North Sea, J. Sea Res., 42, 169-178, 1999.

Whitlock, C. H., L. R. Poole, J. W. Usry, W. M. Houghton, W. G. Witte, W. D. Morris, and E. A. Gurganus, Comparison of reflectance with backscatter and absorption parameters for turbid waters, Appl. Opt., 20(3), $517-522,1981$.

Witte, W. G., C. H. Whitlock, R. C. Harris, J. W. Usry, L. R. Poole, W. M. Houghton, W. D. Morris, and E. A. Gurganus, Influence of dissolved organic materials on turbid water optical properties and remote sensing reflectance, J. Geophys. Res., 87(C1), 441-446, 1982.

Yentsch, C. S., Measurement of visible light absorption by particulate matter in the ocean, Limnol. Oceanogr., 7, 207-217, 1962.

M. Babin, A. Bricaud, and H. Claustre, Laboratoire d'Océanographie de Villefranche, CNRS/UPMC, B. P. 8, F-06238 Villefranche-sur-Mer Cedex, France. (marcel@obs-vlfr.fr; annick@obs-vlfr.fr; claustre@obs-vlfr.fr)

G. M. Ferrari and N. Hoepffner, Space Application Institute, C.E.C., Joint Research Centre, Ispra Site, I-21020 Ispra (Va), Italy. (massimo.ferrari@, jrc.it; nicolas.hoepffner@jrc.it)

G. Obolensky, ACRI ST, 260 Route du Pin Montard, B. P. 234, F-06904 Sophia Antipolis, France. (go@acri-st.fr)

D. Stramski, Marine Physcial Laboratory, Scripps Institution of Oceanography, University of California at San Diego, La Jolla, CA 92093-0238,USA. (stramski@mpl.ucsd.edu) 